NBER WORKING PAPER SERIES

\title{
DID THE RENEWABLE FUEL STANDARD SHIFT MARKET EXPECTATIONS OF THE PRICE OF ETHANOL?
}

Christiane J.S. Baumeister

Reinhard Ellwanger

Lutz Kilian

Working Paper 23752

http://www.nber.org/papers/w23752

\author{
NATIONAL BUREAU OF ECONOMIC RESEARCH \\ 1050 Massachusetts Avenue \\ Cambridge, MA 02138
}

August 2017

This paper was supported by NBER Grant 36269.00.02.00. The views in this paper are solely the responsibility of the authors and should not be interpreted as reflecting the views of the Bank of Canada or the National Bureau of Economic Research. We thank Joseph Aldy, Chris Knittel, Ben Meiselman, and Richard Newell for helpful comments.

NBER working papers are circulated for discussion and comment purposes. They have not been peer-reviewed or been subject to the review by the NBER Board of Directors that accompanies official NBER publications.

(C) 2017 by Christiane J.S. Baumeister, Reinhard Ellwanger, and Lutz Kilian. All rights reserved. Short sections of text, not to exceed two paragraphs, may be quoted without explicit permission provided that full credit, including $(\odot$ notice, is given to the source. 
Did the Renewable Fuel Standard Shift Market Expectations of the Price of Ethanol?

Christiane J.S. Baumeister, Reinhard Ellwanger, and Lutz Kilian

NBER Working Paper No. 23752

August 2017

JEL No. Q18,Q28,Q35,Q42,Q58

\begin{abstract} 2005-06.

Christiane J.S. Baumeister

University of Notre Dame

722 Flanner Hall

Notre Dame, IN 46556

baumeister.2@nd.edu

Reinhard Ellwanger

Bank of Canada

234 Wellington Street

Ottawa, Ontario K1A 0G9

Canada

rellwanger@bank-banque-canada.ca

Lutz Kilian

Department.of Economics

University of Michigan

Ann Arbor, MI 48109-1220

and CEPR

lkilian@umich.edu
\end{abstract}

It is commonly believed that the response of the price of corn ethanol (and hence of the price of corn) to shifts in biofuel policies operates in part through market expectations and shifts in storage demand, yet to date it has proved difficult to measure these expectations and to empirically evaluate this view. We quantify the extent to which price changes were anticipated by the market, the extent to which they were unanticipated, and how the risk premium in these markets has evolved. We show that the Renewable Fuel Standard (RFS) increased ethanol price expectations by as much $\$ 1.50$ initially, raising ethanol storage demand starting and causing an increase in the price of ethanol. There is no conclusive evidence that the tightening of the RFS in 2008 shifted market expectations, but our analysis suggests that policy uncertainty about how to deal with the blend wall raised the risk premium in the ethanol futures market in mid-2013 by as much as 50 cents at longer horizons. Finally, we present evidence against a tight link from ethanol price expectations to corn price expectations and hence to the storage demand for corn in 


\section{Introduction}

Since the creation of the Renewable Fuel Standard (RFS) in 2006, there have been strict mandates governing the use of corn ethanol in producing motor gasoline in the United States. Motor gasoline is produced by refining crude oil and blending the resulting low-grade gasoline with ethanol, which in turn is being produced from corn. At present, close to $10 \%$ of U.S. gasoline sold at the pump consists of corn ethanol, up from 3\% in 2005. The creation of the RFS in the United States has had far-reaching implications for the ethanol market (and indirectly for the market for corn), but little is known about how the ethanol price has responded to the creation of the RFS and its subsequent revisions. Quantifying these effects is complicated by the fact that changes in the RFS are often anticipated by the market, potentially causing price expectations to shift well before the actual shift in policy. These price shifts in turn may cause the spot price of ethanol to increase well in advance of the policy shift, as storage demand for ethanol increases.

Assessing the effect of changes in the RFS on the ethanol market not only entails estimating shifts in ethanol price expectations and measuring ethanol price shocks, but it also involves understanding related developments in the market for corn and in the markets for crude oil and for unfinished motor gasoline. For example, ethanol prices may be affected by poor corn harvests or bumper crops. They may also respond to shifts in the supply of gasoline triggered by refinery outages, to cost shocks associated with shifts in the global price of crude oil and with shifts in the domestic demand for gasoline driven by the U.S. business cycle or by changes in consumer behavior (see, e.g., Coglianese, Davis, Kilian and Stock 2017). Although there have been many analyses of these markets in isolation, only recently attention has been given to the close economic relationship between energy and agricultural markets (see, e.g., Salvo and Huse 
2011; Mallory, Irwin, and Hayes 2012; Baumeister and Kilian 2014; Carter, Rausser and Smith 2017; Bielen, Newell and Pizer 2016).

This paper quantifies to what extent changes in the ethanol spot price have been expected and to what extent they have been unexpected. Our ultimate objective is to distinguish changes in price expectations caused by the changes in the RFS from changes reflecting other determinants. We are also interested in quantifying how the risk premium embodied in futures prices has been affected by changes to the RFS. Answering these questions ideally requires estimates of the market expectations of the spot prices of corn, ethanol, gasoline and crude oil. Given the complexity of the relationship between these four markets, the fact that this relationship is rapidly evolving, and the fact that we only have a few years of data, conventional econometric approaches to estimating price expectations in these markets are of limited use. Nor are there reliable survey data of price expectations from market participants. Thus, currently little is known about the nature of these price expectations and about how their relationship has evolved over time.

Our analysis of this question builds on recent methodological advances in measuring the market expectation of the price of crude oil based on prices of futures contracts. Baumeister and Kilian (2016a) showed that this expectation may be inferred from the prices of oil futures contracts with the help of recently proposed term-structure models of commodity futures markets (see Hamilton and $\mathrm{Wu}$ 2014). These models generate an estimate of the time-varying risk premium in the futures market. Although oil futures prices themselves tend to be poor measures of expectations, especially at short horizons, economically plausible and comparatively accurate measures of oil price expectations may be obtained by adjusting the oil futures price by the estimated risk premium. We apply this methodology to futures prices for crude oil, unfinished 
motor gasoline, and ethanol and construct estimates of price expectations at horizons from 3 months to 12 months for each of these markets. In contrast, we do not include corn futures markets in this analysis. ${ }^{1}$

Our analysis sheds light on a range of issues, from the impact of financial investors in these futures markets to the links between the gasoline and ethanol market. Most importantly, we show that the RFS increased ethanol price expectations by as much as $\$ 1.50$ in the year before and in the year after the implementation of the RFS had started. Our analysis of the term structure of expectations provides support for the view that a shift in ethanol storage demand starting in 2005 in anticipation of the RFS caused an increase in the price of ethanol. Our analysis also suggests that policy uncertainty about how to deal with the blend wall raised the risk premium in the ethanol futures market in mid-2013 by as much as 53 cents at longer horizons. In contrast, there is no conclusive evidence that the tightening of the RFS in 2008 shifted ethanol price expectations. Finally, we present evidence against a tight link from ethanol price expectations to corn price expectations and hence to storage demand for corn in 2005-06, which calls into question some previous accounts of the evolution of the corn price after 2005.

The remainder of the paper is organized as follows. Section 2 provides some institutional background and develops a timeline of changes to the RFS. Section 3 briefly reviews our approach to recovering price expectations from futures prices and establishes the superior accuracy of these estimates compared to alternative measures of expectations. In section 4, we report estimates of the time-varying risk premium, of the expected change in the spot price, and

\footnotetext{
${ }^{1}$ Unlike futures contracts for oil, gasoline or ethanol, which are available for delivery in every month, corn futures contracts only mature five times a year (in March, May, July, September and December), making it impossible to construct time series of corn futures prices with a given maturity or to estimate the corn risk premium. This problem is well known. For example, Carter, Rausser and Smith (2017) deal with this data limitation by specifying a model of the corn market based on annual data. Our approach is different. In section 5, we selectively draw on data for corn futures prices and on data for the cost of corn used in ethanol production in interpreting the evolution of the ethanol market, given the evidence for price expectations and risk premia in the crude oil, gasoline and ethanol markets.
} 
of the unexpected change in the spot price. We examine the evolution of these estimates over time for each of the three markets of interest at horizons ranging from three months to one year, we assess the degree of market integration, and we relate the findings to changes in the RFS. Section 5 examines at what times changes in the RFS shifted the price of ethanol and ethanol price expectations and by how much, and it analyzes whether these expectations shifts are consistent with increased storage demand for ethanol. We also investigate the link between the markets for ethanol and for corn. The concluding remarks are in section 6.

\section{The Renewable Fuel Standard}

Finished motor gasoline sold at retail gas stations in the United States is obtained by blending unfinished motor gasoline, which is obtained by refining crude oil, with ethanol. The percentage of ethanol-equivalent gallons of renewable fuel to gallons of nonrenewable fuel (including diesel and gasoline) in the United States has gradually increased from about 3\% in 2005 to over 9\% in 2010, reaching just under $10 \%$ in 2015 . Ethanol in the United States is primarily produced from corn. Corn ethanol is a renewable fuel, the use of which is mandated under the RFS. The Environmental Protection Agency (EPA) administers the RFS by setting annual targets for the volume of ethanol to be blended with unfinished gasoline in a given year. Given the U.S. Energy Information Administration (EIA) forecast of U.S. gasoline consumption for the coming year, this target is then expressed as the percentage of renewable fuel to be used in finished fuels. Compliance with the law is demonstrated through the acquisition of unique Renewable Identification Numbers (RINs) assigned to every batch of renewable fuel produced domestically or imported.

\subsection{Institutional Background}

The RFS was created by the Energy Policy Act of 2005 and revised in the Energy Independence 
and Security Act (EISA) of 2007. The original intent of the legislator was that the U.S.

renewable fuel consumption targets would steadily increase over time, according to a prespecified time table. For example, the EISA mandated the consumption of 36 billion gallons of renewable fuel by 2022 compared with 3.5 billion gallons in 2004. This objective has become increasingly unrealistic due to the so-called blend wall. Renewable fuel consists mainly of biodiesel and corn ethanol. The blend wall refers to the fact that, given current limits on the ethanol content of finished motor gasoline (E10) of about 10\%, the demand for ethanol is limited by the consumption of finished gasoline, which has been falling in recent years in response to persistently high gasoline prices until mid-2014, increased fuel efficiency, and slow economic growth. ${ }^{2}$ In recognition of the blend wall, the EPA in late 2013 proposed to revise downward its original RFS target for 2014. New RFS targets for 2014 and 2015 were not issued until December 2015, however. The December 2015 EPA decision to raise the renewable fuel content from $9.52 \%$ for 2015 to $10.10 \%$ in 2016 (consistent with a target of 18.11 billion gallons of renewable fuel) appeared to mark another policy shift. Although this decision recognized that the original RFS mandates were infeasible, the 2016 mandate renewed concerns among stakeholders about the blend wall becoming binding.

\subsection{Timeline of Regulatory Changes}

Table 1 develops a timeline of legislative changes to the RFS that allows a comprehensive analysis of the effects of biofuel legislation on ethanol price expectations. The RFS mandates have been revised several times since 2006. There were four major policy shifts between 2005 and 2015: (1) The introduction of the RFS, which became effective in 2006. (2) The tightening

\footnotetext{
${ }^{2}$ Restrictions on the ethanol content of motor gasoline arise from the fact that automobile manufacturers accept no liability in general for damages to cars associated with the use of motor gasoline with more than about $10 \%$ fuel ethanol content (referred to as E10). The concern is that ethanol is corrosive and tends to weaken the integrity of pipes, valves, hoses, pumps, carburetors, and related equipment. Even increasing the ethanol content to 15\% (E15) traditionally has been considered unsafe in operating many vehicles, especially older cars.
} 
of the standard, which became effective in 2008. (3) The November 2013 proposal to lower the RFS mandate for 2014, followed by a suspension of the RFS mandate for 2014. (4) The announcement in late 2015 of retroactive targets for 2014 and 2015 that exceeded the 2013 proposal, but remained far below the original RFS targets, and a new somewhat higher RFS target for 2016 that was widely perceived to ignore the blend wall.

In studying the effects of changes in the RFS on price expectations, it is not enough to note the date of the change, but also the date at which the change could have been anticipated by an informed observer. For each change to the RFS, the left panel of Table 1 lists the dates at which the legislative change could have been anticipated, whereas the right panel provides the dates when the change became the law. For example, even granting that the final version of the Energy Policy Act that was signed into law in August 2005 was not identical with the House version, it is reasonable to presume that the introduction of the RFS could have been anticipated as early as April 2005, when the original version of the bill passed the House. Likewise, the Energy Independence and Security Act (EISA) of December 2007 was passed by the House already in January 2007.

The EPA typically administers the RFS by proposing to set an annual RFS target for the following year, followed by a public hearing and a final announcement shortly before the beginning of the year in which the target becomes binding. With the exception of the changes triggered by the passing of the EISA, EPA announcements of RFS targets traditionally have tended to be perfectly predictable in that they merely restated the targets already articulated by the legislator. Thus, the passing of the EISA represented a policy shift, but other RFS proposals and announcements between 2006 and 2012 did not and hence are not listed in Table 1.

The third major policy shift occurred in 2013. This policy shift occurred gradually 
starting with the EPA proposal of February 2013 which reaffirmed the RFS mandate for 2013, but signaled the possibility of a shortage of RINs in 2014 under the originally planned RFS mandate for 2014. The EPA's final rule for 2013 dated August 2013 for the first time explicitly recognized the blend wall as a constraint on ethanol consumption in 2014. The November 2013 EPA proposal outlined substantially lower RFS targets for 2014. The substance of this proposal was leaked to the press in early October 2013, well before its official release. Following extensive discussions with stakeholders, the EPA's final ruling on the 2014 mandate was withdrawn in December 2014, and no further instructions for 2014 or 2015 were issued by the EPA until the end of 2015. A conservative assessment therefore is that this proposal may have been anticipated by some market participants as early as August 2013.

Finally, as of June 2015, the EPA proposed to raise the RFS targets slightly relative to its November 2013 draft proposal. The latter proposal in turn was tightened again in the final ruling in late November 2015, which also included an RFS target slightly above the blend wall for 2016, representing another policy shift.

\section{Estimating Price Expectations}

The main question of interest in this paper is by how much the regulatory changes documented in Table 1 have affected the expectation of the price of ethanol. The answer to this question is important not only in its own right, because it sheds light on the extent to which markets anticipate changes in economic policy, but it is important more generally for understanding the evolution of the spot price of ethanol and of related spot prices such as the price of corn that are important for consumers of food (see Roberts and Schlenker 2013; Baumeister and Kilian 2014, Wright 2014). Quantifying the effects of changes in the RFS is challenging because these policy shifts took place in an environment of important changes in the prices of crude oil and of 
unfinished motor gasoline as well as changes in the price of corn, which is the major feedstock in the production of ethanol. It is also challenging more generally because of the difficulty of measuring market expectations.

Our analysis addresses this challenge by utilizing a recently developed approach to constructing market expectations of commodity prices based on data for weekly futures prices (see Baumeister and Kilian 2016a). We develop estimates of the price expectations for crude oil, unfinished motor gasoline, and ethanol at horizons of 3, 6, 9, and 12 months. For each futures market of interest, we fit the term-structure model of Hamilton and Wu (2014) - suitably adapted to accommodate the differences in the timing of the contracts across markets. This model, henceforth referred to as the HW model, generates an estimate of the time-varying risk premium for each market. ${ }^{3}$ The risk premium may be viewed as the product of the level of risk and of the price of risk. Estimates of the risk premium not only help assess the degree of market integration across commodities, but, as emphasized in Baumeister and Kilian (2016a, b, c), they may be used to recover the market expectation of the spot price of the commodities traded in futures markets. Let $F_{t}^{h}$ denote the dollar price of a futures contract purchased in the current month that is expiring $h$ months later, let $S_{t+h}$ denote the spot price prevailing at the expiry date of the futures contract and $R P_{t}^{h}$ the risk premium embodied in $F_{t}^{h}$. Then $E_{t}\left(S_{t+h}\right)=F_{t}^{h}+R P_{t}^{h}$. Hence, knowledge of the risk premium facilitates the construction of the price expectation.

Recently, Baumeister and Kilian (2016a) demonstrated that measures of the futures market's expectations of the West Texas Intermediate (WTI) price of crude oil constructed in

\footnotetext{
${ }^{3}$ Hamilton and $\mathrm{Wu}$ (2104) develop a two-factor term-structure model for storable commodities. Their model embodies an affine factor structure for futures prices. Estimation of the model only requires data for futures prices on the last day of each week. Time-varying risk premia are obtained as the difference between the observed futures price and the rational expectation of the futures price implied by the estimated structural model under the counterfactual assumption of a zero risk premium.
} 
this manner are more accurate statistically and more plausible economically than alternative methods of estimating these price expectations discussed in the literature. We apply the same approach to the futures markets for Brent crude oil, U.S. unfinished motor gasoline and ethanol. An important advantage of this approach compared with alternative regression-model-based estimates of price expectations is that we do not have to take a stand on the nature of the potentially nonlinear relationship between the crude oil, gasoline and ethanol markets (see Serra et al. 2011; Abbott 2014; Baumeister and Kilian 2014; Wright 2014). The precise nature of this nonlinear relationship is unknown and so complicated as to render other regression-based approaches to estimating the time-varying risk premium infeasible. In contrast, our approach allows us to estimate the risk premium for each market one at a time, with the understanding that whatever role nonlinearities as well as interdependencies across markets play in determining price expectations is incorporated in financial market expectations by construction.

\subsection{Data and Estimation Period}

All futures prices were obtained from Bloomberg. The gasoline traded in futures markets refers to Reformulated Gasoline Blendstock for Oxygen Blending (RBOB). The spot prices of unfinished motor gasoline and of Brent crude oil are from the EIA. We focus on the Brent futures price rather than the WTI futures price because of evidence that the U.S. price of gasoline is determined by the price of gasoline in global markets, which in turn depends on the price of crude oil in global markets. The latter price may be approximated by the price of Brent crude (see Borenstein and Kellogg 2013; Kilian 2014). Throughout the paper, the price of oil is converted from $\$$ /barrel to $\$$ /gallon. ${ }^{4}$ Additional data on the total cost and the breakeven price of ethanol production as well as the ethanol producer price are from Hofstrand (2016).

\footnotetext{
${ }^{4}$ One barrel of crude oil consists of 42 gallons of oil.
} 
Hamilton and Wu (2014) estimate their term-structure model of the WTI oil futures market separately on a subsample ending in December 2004 and a subsample starting in January 2005 to allow the model parameters to change in response to the increased financialization of commodity futures markets after 2004 (also see Fattouh et al. 2013). Our analysis is consistent with theirs in that we do not include pre-2005 data in estimating the model. Our estimation period starts in January 2005, except for the ethanol futures market. Ethanol futures prices for the maturities of interest in this paper are available only starting in September $2005 .{ }^{5}$ Given that the RFS was passed by the House in April 2005, was enacted in August 2005, and became effective in January 2006, the sample starts early enough to allow us to assess whether the imposition of the RFS was anticipated by the market. The sample ends in December 2015.

\subsection{The Evidence in Support of the HW Model}

Although there are few alternatives to the HW model in estimating the price expectations prevailing after 2004 in the markets for Brent crude oil, for unfinished gasoline and for ethanol, there are some alternatives. For example, one could rely on futures prices as a proxy for the expectation, as in Carter, Rausser and Smith’s (2017) analysis of the corn market. Alternatively, one could rely on a no-change prediction. In the case of gasoline markets, at the 12-month horizon, yet another option would be to rely on survey expectations for the change in the retail price of gasoline from the Michigan Survey of Consumers (see Anderson, Kellogg and Sallee 2013).

For the expectations estimates based on the HW model to be credible, it is necessary to

\footnotetext{
${ }^{5}$ An additional complication in assessing the ethanol price expectations is that there was a shift in the expiry date of ethanol futures contracts in September 2006. Prior to this date, trading ceased one business day before the $15^{\text {th }}$ calendar day of the month preceding the delivery month, whereas subsequently contracts expired on the $3^{\text {rd }}$ business day of the delivery month. The first subsample is too short for the estimation of the HW model. We deal with this complication by applying the parameter estimates obtained from the post-August 2006 sample for the first, second, third, and fourth week of the contract to the corresponding week of the contracts in the first subsample.
} 
demonstrate that these estimates are more accurate than the alternatives outlined above (see Baumeister and Kilian 2016a). The conventional measure of the accuracy of price expectations is the mean-squared prediction error (MSPE), defined as $E\left[S_{t+h}-E_{t}\left(S_{t+h}\right)\right]^{2}$ (see, e.g., Anderson et al. 2013). If adjusting the futures price for the HW estimate of the risk premium produces an expectations measure with higher MSPE than the unadjusted futures price, for example, the model-based expectations measure is inadmissible and the unadjusted futures price would be the preferred measure of expectations. Without loss of generality, all MSPE results in our empirical analysis are expressed as ratios relative to the corresponding MSPE of the no-change prediction. A ratio below unity indicates an improvement in accuracy on the no-change prediction.

Table 2 focuses on the Brent price of crude oil. The risk-premium-adjusted oil futures price is more accurate than the unadjusted oil futures price at every horizon, often by a wide margin. It also is more accurate than the no-change prediction at every horizon. The improvements in accuracy with respect to the no-change prediction are statistically significant at all horizons. For example, at the 12-month horizon, the reduction in the MSPE compared with the no-change prediction is $34 \%$. Compared with the Brent futures price, it is $23 \%$. In contrast, the unadjusted oil futures price fails to systematically improve on the accuracy of the no-change prediction.

Turning to the futures market for unfinished gasoline, Table 3 shows that the gasoline futures price is more accurate than the no-change forecast of the price of gasoline at every horizon. The reduction in the MSPE compared with the no-change prediction ranges from 11\% to $19 \%$. The risk-premium-adjusted gasoline futures price is still more accurate than the unadjusted futures price and statistically significant at every horizon, however, with MSPE reductions as large as $36 \%$. The risk-adjusted futures price also is substantially more accurate 
than the 12-month gasoline price expectation implied by the median survey response in the Michigan Survey of Consumers, which is available starting in February 2006.

Finally, Table 4 suggests that ethanol futures prices are fairly accurate predictors compared with the no-change prediction, typically yielding MSPE reductions of 20\% or more, but the gain in accuracy is not always statistically significant. The risk-premium-adjusted ethanol futures price is even more accurate at every horizon, yielding statistically significant MSPE reductions of up to $40 \%$ compared with the no-change prediction. ${ }^{6}$ We conclude that Tables 1,2 , and 3 provide clear empirical support for the use of the HW model in constructing price expectations for Brent crude oil, unfinished motor gasoline and ethanol.

\section{What Do We Learn from the HW Model Estimates?}

The HW term-structure model generates estimates for the time-varying risk premium and allows us to infer the expected change in the spot price as well as the unexpected change in the spot price at every point in time. This section examines the evolution of these estimates over time for each of the three markets of interest at horizons ranging from three months to one year. We also assess the degree of market integration, and we search for evidence of shifts in expectations that are associated with the changes in the RFS in Table 1.

\subsection{The Risk Premium in the Markets for Brent Crude, Unfinished Gasoline and Ethanol}

Commercial producers of a commodity such as oil, gasoline or ethanol often use futures contracts to hedge against commodity price risk. The financial investors who take the other side of these contracts typically receive some monetary compensation for taking the non-diversifiable price risk off the hands of the producer. This risk premium tends to change over time, as perceptions of market risk change and as the composition of the futures market participants

\footnotetext{
${ }^{6}$ Very similar results are obtained if we restrict attention to the data since August 2006 (see footnote 5).
} 
evolves. The risk premium may even turn negative. For example, Hamilton and Wu (2014) suggest that rising buying pressure from commodity-index funds may explain a reversal in the sign of the risk premium in the crude oil futures market in 2008.

Figure 1 plots the risk premium estimates in the futures markets for Brent crude oil, unfinished U.S. motor gasoline and U.S. ethanol. We focus on horizons of 3, 6, 9, and 12 months. The sign of the risk premium has been normalized such that $F_{t}^{h}=E_{t}\left(S_{t+h}\right)-R P_{t}^{h}$, where $F_{t}^{h}$ denotes the current dollar price of a futures contract expiring $h$ months later, $S_{t+h}$ denotes

the spot price prevailing at the expiry date, and $R P_{t}^{h}$ is the risk premium embodied in $F_{t}^{h}$. Dates of proposed and actual changes to the RFS, as discussed in Table 1, are shown as vertical lines.

\subsubsection{One Risk Premium? The Role of Index Fund Traders}

An obvious question is how integrated these three futures markets are, as measured by the risk premium. There is a large literature arguing that commodity futures markets since 2004 have become increasingly dominated by financial investors such as index fund investors. A common view is that these markets have become increasingly integrated with one another and with other asset classes such as equities, resulting in a "market of one” (see Büyükşahin, Haigh, and Robe 2010; Tang and Xiong 2012; Silvennoinen and Thorp 2013; Büyükşahin and Robe 2014). To the extent that changes in index fund positions are the primary determinant of the risk premium, one therefore would expect the evolution of the risk premium to be similar across the markets for oil, gasoline and ethanol. In contrast, if changes to the RFS affected the risk premium, one would expect the ethanol risk premium to evolve differently from the risk premium in oil and gasoline markets.

Figure 1 shows that the comovement across the risk premia is far from perfect. The evolution of the time-varying risk premium in the Brent and unfinished gasoline markets is 
broadly similar. For example, both Brent and unfinished gasoline show a sharply negative risk premium in 2008, especially at longer horizons. There is a similar, but much more muted, negative risk premium in the ethanol market as well. Likewise, the risk premium between 2011 and 2012 tends to be negative in all three markets, at least at longer horizons. Until 2007, in contrast, the risk premium tends to be positive in all three markets.

There are some equally striking differences, however. For example, the risk premium in the unfinished gasoline market is much higher than in the Brent market until 2007 and in 201516. There also is large positive risk premium in the gasoline market in 2009-10 not found in either the crude oil or the ethanol market. Moreover, the ethanol risk premium is very high in 2005 at longer horizons, whereas the other risk premia are not. The ethanol risk premium also spikes in 2013 (again, only at longer horizons) without a similar shift in other markets.

We conclude that despite some commonalities, each time-varying risk premium is distinct. This conclusion is corroborated by Table 5, which shows that the correlation between the oil and gasoline risk premium steadily increases with the horizon from $74 \%$ at the 3 -month horizon to $89 \%$ at the 12-month horizon. In contrast, the correlation between the oil and ethanol risk premium is much lower, ranging from $39 \%$ at the 3-month horizon to at most $53 \%$ at longer horizons. The correlation between the risk premium for unfinished motor gasoline and ethanol in turn is highest at the 3-month horizon with $59 \%$, but drops off steadily at longer horizons to $41 \%$ at the 12-month horizon. Full market integration due to financialization would correspond to the risk premia being perfectly correlated across futures markets. The evidence speaks against the hypothesis that these markets are fully integrated.

\subsubsection{Has RFS Regulation Shifted the Risk Premium in the Ethanol Market?}

We now turn to the question of whether there is evidence of regulatory changes in the RFS 
having shifted the ethanol risk premium. It is worth noting that, with the exception of late 2005 and 2013, there is no evidence of large positive ethanol risk premia during periods of changes to RFS regulations (indicated by vertical lines in the figure). The fact that the ethanol risk premium declined sharply in late 2005 in principle could be explained by declining uncertainty about the future of biofuels. It could also be explained by an influx of financial investors through index funds.

The fact that after mid-2014 the risk premium was rising in the oil and gasoline market is consistent with a decline in financial investor participation in the oil and gasoline market, following the sharp drop in the prices of oil and gasoline after June 2014 (see Baumeister and Kilian 2016b). It is also consistent with an increase in uncertainty in these markets. The risk premium for ethanol remained flat after June 2014, in contrast. A likely explanation is that the RFS ensured stable demand for ethanol, notwithstanding the turmoil in oil and gasoline markets.

Of particular interest is the spike in the ethanol risk premium in 2013, which also coincided with a similar spike in RIN prices (see Stock 2015). As discussed in section 2, the RIN is the mechanism used by the EPA to record compliance with the RFS. Stock (2015) attributes this spike primarily to increasing awareness of the blend wall in conjunction with concerns about a growing shortage of RINs, triggered by the February 2013 EPA rule. These concerns appear to have subsided starting in August 2013, when the EPA first hinted that RFS mandates may have to be lowered. The decline continued after the EPA proposal for 2014 was leaked in October 2013, with the RIN price returning to its original level by December 2013.

Figure 1 shows a very similar pattern in the ethanol risk premium. Although there is little movement in the 3-month risk premium, all longer-term risk premia show a sharp peak between February 2013 and December 2013, which increases with the horizon. The 12-month risk 
premium, for example, increases by 53 cents. One interpretation of this evidence is that the August 2013 EPA proposal was acted upon by informed parties, resulting in an outflow of financial investors from the ethanol futures market in early 2013 and their return into the market in late 2013. A complementary interpretation is that the rising risk premium in early 2013 reflected increasing policy uncertainty, which was resolved in late 2013. If either of these interpretations is correct, the decline in the risk premium in late 2013 would be a striking example of a policy shift affecting the risk premium. It should be noted that there is no mechanical link between RIN prices and the risk premium. For example, ethanol RIN prices were largely flat prior to 2013 and there is no evidence that a smaller spike in RIN prices in late 2015 is mirrored by changes in the ethanol risk premium.

\subsection{Price Expectations}

It is not clear ex ante how much comovement one would expect between the price expectations for Brent crude oil, unfinished motor gasoline and ethanol. Although the price of crude oil is the single most important determinant of the cost of producing unfinished motor gasoline, the price of unfinished gasoline is also affected by refinery shutdowns as a result of routine maintenance, accidents and hurricanes (see, e.g., Kilian 2010), it is affected by changes in the structure of the refining market (see, e.g., Borenstein and Kellogg 2014; Kilian 2014), and it responds to changes in the market power of refiners (see, e.g., Borenstein and Shepard 2002; Gilbert and Hastings 2005; Sweeney 2015). Likewise, the price of ethanol is subject to cost shocks from poor corn harvests and changes in RFS regulations. The methodology outlined in section 3 allows us to address this question and to ask, more specifically, what the evidence is that ethanol price expectations shifted in anticipation of the RFS. As a first step, in Figure 2 we plot the $E_{t}\left(S_{t+h}\right)$ measure constructed based on the HW model estimate of the risk premium for each of the three 
markets.

\subsubsection{Did Ethanol Price Expectations Change before or during RFS Policy Shifts?}

The Energy Policy Act was signed into law in early August 2005. It was scheduled to become effective as of January 2006. It is thus conceivable that expectations of the price of ethanol increased starting in August 2005, in anticipation of the law becoming effective in January 2006. Figure 2, however, shows little or no evidence of an increase in the expected price of ethanol at short horizons in late 2005. The longer horizons ethanol price expectations in late 2005 are higher than the short-horizon expectations, but they fall sharply as we approach the implementation of the Energy Policy Act. Only in 2006, after the RFS had been enacted, do we see a spike in ethanol price expectations, especially at short horizons.

Likewise, the expected price of ethanol remains fairly stable in the period leading up to the implementation of the EISA. Only after the tighter RFS mandates have been implemented, the expected price of ethanol rises sharply, but that increase is mirrored by a similar increase in Brent price expectations and expectations for the price of unfinished motor gasoline, suggesting that the cause of this increase is not the tightening of the RFS but rising global demand for gasoline. The key difference is that ethanol price expectations remain much more stable during the financial crisis in late 2008 than Brent and gasoline price expectations, presumably because the RFS ensured more stable demand for ethanol.

There is another rise in ethanol price expectations in 2011-13, not unlike the persistent increases in gasoline and Brent oil price expectations, but generally starting slightly later. Longer-horizon ethanol price expectations systematically decline toward the end of the sample, after the EPA shifted its policy stance in late 2013 toward lower mandates. This decline occurred 
well before oil and gasoline price expectations started coming down in mid-2014. ${ }^{7}$

We conclude that there is little prima facie evidence of a shift in ethanol price expectations caused by the anticipation of changes in the RFS, but some evidence of ethanol price expectations rising faster than oil and gasoline price expectations in 2006. This conclusion, however, is at best tentative. One concern is that the effect of changes to the RFS may be masked by offsetting changes in other determinants of ethanol price expectations. We defer a more careful analysis of this issue to section 5. An additional concern is that it is difficult to interpret the price expectations data in isolation without some benchmark. This second concern may be addressed by decomposing the observed change in the spot price into the component that was expected by the market and the component that was unexpected:

$$
S_{t+h}-S_{t}=E_{t}\left(S_{t+h}\right)-S_{t}+S_{t+h}-E_{t}\left(S_{t+h}\right)
$$

where $E_{t}\left(S_{t+h}\right)$ is constructed based on the HW model estimate of the risk premium, as discussed earlier. The first term on the right-hand side, $E_{t}\left(S_{t+h}\right)-S_{t}$, denotes the expected change in the spot price, and the second term, $S_{t+h}-E_{t}\left(S_{t+h}\right)$, denotes the unanticipated component (also known as the price shock). Separating these two components of the change in the spot price helps assess the question of whether the price changes around the time of the introduction of the RFS were anticipated by the market or came as a surprise. It also allows us to determine whether these surprises and expectations shifts were specific to the ethanol market or were mirrored by similar developments in oil and gasoline markets. In subsection 4.2.2, we characterize the

\footnotetext{
${ }^{7}$ An interesting question in this context is whether the expiry of the volumetric ethanol tax excise tax credit (also known as the blender tax credit) in December 2011 caused a shift in ethanol price expectations. Such a response might have been expected, given evidence in Bielen et al. (2016) that about two thirds of the incidence of this tax credit (amounting to 30 cents per gallon) accrued to ethanol producers. Figure 2, however, provides little support for an increase in ethanol price expectations in 2012 or in the months leading up to this event. There was at best a short-lived and gradual increase in the 3-month price expectation by 13 cents per gallon in 2012 and none at longer horizons. One possible explanation is that the increases in ethanol volumes mandated under the RFS exceeded what ethanol producers would have produced in the absence of the RFS if the tax credit had continued.
} 
expected change in the spot prices of crude oil, gasoline and ethanol by horizon. The price surprises are examined in subsection 4.2.3.

\subsubsection{Expected Changes in the Price}

A positive value of $E_{t}\left(S_{t+h}\right)-S_{t}$ indicates that the market expects the spot price to increase at horizon $h$, whereas negative values indicate expectations of falling spot prices. Figure 3 shows that the market expected the price of Brent to increase at all horizons from early 2005 until late 2007. At longer horizons, the market expected the Brent price to decline as early as late 2007, but at the 3-month horizons the expected change remained close to zero even in early 2008, indicating that the market expected a modest longer-term oil price decline, but remained unsure of the exact timing. By July 2008 the expected decline in the Brent oil price peaked at \$28 per barrel at the 12-month horizon. The market missed the turning point in the evolution of the spot price, but by October 2008, market participants expected rising prices at least at longer horizons. This assessment changed again in 2011, when the expected change in the Brent price of oil turned negative at all horizons, but more so at longer horizons. At this point the market expected a decline of about $\$ 17$ per barrel a year later. Interestingly, following the sharp decline in the Brent price after June 2014, by September 2014, the market expected the oil price to rebound substantially within a year. For example, as of December 2015, it expected the price to increase by $\$ 21$ per barrel by December 2016 .

For unfinished motor gasoline, Figure 3 paints a similar picture overall, with some notable differences. Prior to 2008, between 2009 and 2014, and after 2014, the expected change in the gasoline price is considerably more volatile and shows larger amplitude. For example, there are expectations of an increase in the price of gasoline by about twice as much as the expected increase in the price of Brent crude oil at the 6-month, 9-month and 12-month horizon 
in the second half of 2015.

As to ethanol, the pattern of expected price changes is qualitatively different than for Brent and gasoline in 2005-07. For example, the market expected ethanol prices to fall at longer horizons, at a time when oil and gasoline prices were expected to rise. Between 2008 and the end of the sample, the pattern of expected ethanol price changes is qualitatively similar to oil and gasoline, but there is a noticeable increase in their volatility at all horizons starting in 2014 .

Table 6 confirms the impression of a lower degree of comovement between ethanol and each of the other two markets than between oil and gasoline. Whereas the correlation between the expected Brent price change and gasoline price change increases from $65 \%$ at the 3-month horizon to $87 \%$ at the 12 -month horizon, the correlation between the expected oil price and ethanol price changes is much lower. It ranges from $32 \%$ at the 3 -month horizon to $59 \%$ at the 12-month horizon. Likewise, the correlation with the expected change in gasoline prices is only slightly higher, ranging from $42 \%$ to $64 \%$.

\subsubsection{Unexpected Price Changes}

Whereas Figure 3 focuses on the anticipated component of the price changes in the Brent oil, unfinished gasoline and ethanol markets, the evidence in Figure 4 is complementary in that it quantifies the extent to which the market was surprised by the evolution of these prices. Such surprises (or price shocks) are defined as $S_{t+h}-E_{t}\left(S_{t+h}\right)$, where $E_{t}\left(S_{t+h}\right)$ is again constructed based on the HW model estimate of the risk premium. We first address the question of how surprised the market was by the changes in oil, gasoline and ethanol prices that took place after 2005.

Figure 4 shows a high degree of comovement between oil price shocks and gasoline price shocks at all horizons. This visual impression is supported by the very high correlation of oil 
price shocks and gasoline price shocks in Table 7. Even at the 3-month horizon, the correlation is 94\% and at longer horizons the correlation falls only slightly. The corresponding correlations between oil price shocks and ethanol price shocks and between gasoline price shocks and ethanol price shocks are lower, ranging from about $50 \%$ to about $77 \%$. Much of this difference is driven by the data for 2005-07 and for 2013-15. For example, there is evidence of a series of positive temporary ethanol price shocks in late 2005 and early 2006, followed by negative ethanol price shocks at longer horizons, indicating that the market initially underpredicted and then overpredicted the spot price of ethanol. There is also evidence of large positive ethanol price shocks in 2013 at all but the 12-month horizon, but much less evidence of large negative ethanol price shocks in 2014-15 than in the Brent and gasoline markets.

The last column of Figure 4 allows us to answer the question of how surprised the ethanol market was by changes in the RFS. For example, there is clear evidence that the market was taken by surprise by the increase in the ethanol price that took place before and after the imposition of the RFS. What the ethanol market missed was the extent of the temporary price boom in ethanol in 2006. Specifically, there is a large 3-month ethanol price shock in early 2006, whereas the 6-month and 9-month price shock series already peak in late 2005. In contrast, the 12-month price shocks are negligible because at the horizon of the 12-month expectation, the price of ethanol had reverted back to lower levels already. In conjunction with the evidence in Figure 3, one may infer that the price boom of 2005/06 was only imperfectly anticipated.

Figure 4 shows additional positive ethanol price shocks during the tightening of the RFS standard in 2007, especially at horizons 6 and 9, followed by large negative price shocks in late 2007 and 2008. At first this evidence may seem supportive of the view that the change in regulatory policy affected the ethanol price. A key difference compared with the introduction of 
the RFS in 2005-06, however, is that this pattern mirrors the qualitative patterns found for Brent crude and for gasoline over this period. Thus, a more plausible interpretation of this evidence is a common shift in the demand for these commodities. In contrast, the positive ethanol price shocks in late 2013 and early 2014 are not accompanied by similar oil or gasoline price shocks. These price shocks are clearly ethanol-specific. They also are temporary. Finally, as to the EPA announcement in late 2015, there is only limited information to date, but no indication of the market having been surprised one way or the other.

\section{Quantifying the Effects of the RFS in 2006 and 2008}

If we are interested in quantifying the effects of changes in the RFS, it is not enough to measure ethanol price shocks and shifts in ethanol price expectations around the time of policy shifts because the price of ethanol may move for a variety of other reasons. For example, increases in the cost of the corn feedstock tend to be associated with higher ethanol prices. The cost share of corn in ethanol historically has ranged from $40 \%$ in late 2005 to near $85 \%$ in 2012. An analysis of cost pressures in the ethanol market is further complicated by the existence of indirect subsidies for ethanol production. ${ }^{8}$ Figure 5 plots the total cost of ethanol production in dollars per gallon (which varies largely with the cost of corn feedstock) and the producer price of ethanol. It also plots the breakeven price, defined as total cost minus indirect subsidies. Figure 5 shows that from 2008 until early 2013, the price of ethanol closely tracked the breakeven price. There are only two episodes when the price of ethanol increased substantially and persistently relative to the breakeven price. One is between 2005 and the end of 2007. The other lasted from late 2013 until the end of 2014. The fact that from 2005 until late 2006 the breakeven price (as well as the cost of corn) remained largely unchanged is particularly helpful in identifying the effects of the

\footnotetext{
${ }^{8}$ These indirect subsidies consist of subsidies for distillers' dried grains with solubles (DDGS) that accrue as a byproduct of ethanol production and are sold as animal feed.
} 
imposition of the RFS in 2006.

In the absence of shocks to the breakeven price, the price of ethanol depends on the demand for ethanol. Provided that unfinished gasoline and ethanol are blended in fixed proportions, in the absence of RFS changes, one would expect the demand for ethanol to be jointly determined with the demand for unfinished motor gasoline. Higher domestic (or export) demand for finished gasoline results in higher gasoline and ethanol prices, but not every increase in gasoline prices reflects higher demand. For example, refinery shutdowns resulting from natural disasters such as Hurricanes Rita and Katrina in late August and late September 2005 may reduce the supply of gasoline, causing sharp, if temporary, gasoline price increases. Such gasoline supply shocks do little to affect gasoline price expectations at horizons of three months or longer and hence can be ignored.

Changes in the price of unfinished gasoline also reflect changes in the cost of crude oil. The cumulative percentage change in the price of Brent crude oil in the second half of 2008, which is clearly driven by the financial crisis rather than a shift in U.S. gasoline demand, is almost identical to the cumulative change in the price of unfinished motor gasoline over the same period. This fact is suggestive of a cost share of crude oil in the production of unfinished motor gasoline that is close to one. ${ }^{9}$ As Figure 6 illustrates, changes in the spot price of crude oil explain the bulk of the observed changes in the spot price of unfinished motor gasoline. There are some deviations. For example, there is evidence that the gasoline price in September and October 2005 increased by more than the price of crude oil, providing direct evidence of the effect of the gasoline supply shock caused by Hurricanes Rita and Katrina in the months leading up to the introduction of the RFS. Such episodes are rare, however. Abstracting from refinery

\footnotetext{
${ }^{9}$ This conclusion contrasts with a much lower cost share of crude oil of near $50 \%$ in finished motor gasoline (see Baumeister and Kilian 2017).
} 
outages, a reasonable working assumption is that increases (decreases) in the price of gasoline in excess of increases (decreases) in the price of Brent crude oil are driven by shifts in the U.S. demand for unfinished motor gasoline. Implicitly, this working assumption treats the contribution of the U.S. demand for crude oil to the Brent price of crude oil as negligible. This assumption is best thought of as providing a lower bound on the effects of shifts in U.S. gasoline demand on the U.S. price of unfinished gasoline that provides a useful benchmark in the analysis below.

\subsection{Constructing a Counterfactual}

In order to assess the impact the imposition of the RFS has had on ethanol price expectations, we need to construct a counterfactual that controls for confounding factors. As of April 2005, when the House passed the Energy Policy Act, the price of ethanol approximately equaled the breakeven price. The fact that from 2005 until late 2006 the breakeven price (as well as the cost of corn) remained largely unchanged is particularly helpful in identifying the effects of the imposition of the RFS in 2006. Our baseline counterfactual takes the breakeven price of ethanol as given and asks by how much we would have expected ethanol price expectations to increase relative to the breakeven price in the absence of the RFS. For the time being, we defer the question of whether the RFS raised the price of corn and hence the breakeven price, and focus on the demand side of the ethanol market. There are two sources of demand for ethanol. Demand for ethanol may reflect expected or actual changes in the RFS. It may also result from shifts in the demand for unfinished gasoline. Our working assumption is that unfinished gasoline and ethanol are blended in approximately fixed proportions (also see Baumeister and Kilian 2014). If this assumption is correct and if the price elasticity of supply is the same in both markets, one would expect the price of ethanol to increase at the same rate as the price of unfinished gasoline in 
response to shifts in the demand for unfinished gasoline. Given the cost of producing ethanol, this allows us to infer approximately by how much the price of ethanol would have been expected to increase after January 2005 in the absence of any change to the RFS. In short, this counterfactual expected ethanol price at horizon $h$ can be written as

$$
E_{t}\left(S_{t+h}^{\text {ethanol, counterfactual }}\right)=B E P_{t}\left(1+\frac{\left(E_{t}\left(S_{t+h}^{\text {gas }}\right)-E_{t}\left(S_{t+h}^{\text {Brent }}\right)\right)}{S_{t}^{g a s}}\right),
$$

where all prices are expressed in dollars/gallon, $B E P_{t}$ is the breakeven price of ethanol (defined as total production cost - indirect subsidies), $E_{t}\left(S_{t+h}^{\text {gas }}\right)-E_{t}\left(S_{t+h}^{\text {Brent }}\right)$ denotes the expected change in the dollar price of unfinished motor gasoline driven by U.S. demand, and $\left(E_{t}\left(S_{t+h}^{g a s}\right)-E_{t}\left(S_{t+h}^{\text {Brent }}\right)\right) / S_{t}^{\text {gas }}$ denotes the corresponding expected percentage change in the price of unfinished motor gasoline.

This counterfactual deliberately ignores expected changes to the cost of corn. Effectively, we are operating under the assumption that changes to the cost of producing ethanol are unpredictable. It may seem that this counterfactual could be improved by suitably adjusting the breakeven price for the expected change in the price of corn. There are several reasons not to make such an adjustment. First, not only are corn price expectations difficult to measure, as discussed in more detail below, but higher expected demand for unfinished motor gasoline is likely to increase the demand for ethanol and the derived demand for corn, resulting in higher corn price expectations. Hence, adjusting the counterfactual for expected changes in the price of corn runs the risk of double counting the effects of higher gasoline demand on ethanol price expectations. Second, changes in corn price expectations may also result from changes in expected demand caused by the RFS. Including such shifts in corn price expectations in the 
counterfactual would cause us to underestimate the effects of changes in the RFS on ethanol price expectations. Thus, we do not incorporate expectations of corn prices in the counterfactual. The cost of ignoring corn price expectations is that the counterfactual ignores the effect of predictably poor or predictably bountiful corn harvests on the expected cost of producing ethanol. This omission may cause the counterfactual to overstate or understate the causal effects of changes to the RFS, but such errors should be short-lived.

Figure 7 plots both the price expectation of ethanol and the counterfactual price expectation between January 2005 and June 2008. This period covers the major changes to the RFS stemming from the 2005 Energy Policy Act and the 2007 Energy Independence and Security Act. The difference between these time series, as shown in Figure 8, is an estimate of the effect of changes in the RFS on the price expectation of ethanol, conditional on the breakeven price (and implicitly conditional on the price of corn).

\subsubsection{The 2005 Energy Policy Act}

Figures 7 and 8 help address the question of how large the effect of the imposition of the RFS was on ethanol price expectations and how forward-looking the response of the market was. The figures show clear evidence of ethanol price expectations having risen by as much as $\$ 1.18$ per gallon at longer horizons in September 2005, consistent with the view that price expectations rose in anticipation of the RFS. ${ }^{10}$ Although our ethanol price expectations data only start in September 2005, there is indirect evidence that this surge in expectations already started in May

\footnotetext{
${ }^{10}$ The analysis of the 3-month price expectation is complicated by the fact that in September and October the spot price of gasoline had spiked, when Hurricanes Rita and Katrina disrupted gasoline production along the Gulf of Mexico. It was understood, however, that this disruption would be temporary. The 3-month-ahead expectations of the price of unfinished gasoline rose sharply in August 2005 and peaked in September, but fell quickly after September 2005. By November 2005, it had returned to its pre-August level. Thus, the 61 cents by which the 3month price expectation for ethanol exceeded that for gasoline in November are likely to be an accurate estimate of the anticipated effect of the introduction of the RFS on the 3-month ethanol price expectation. For longer-run price expectations, the gasoline supply disruption caused by these hurricanes may safely be ignored.
} 
2005. The fact that the spot price of ethanol coincided with the breakeven price in April 2005, when the Energy Policy Act passed the House, is particularly informative (see Figure 5). With the cost of producing ethanol not changing materially until late 2006, the sustained increase in the spot price of ethanol after April 2005 is difficult to explain if not as a response to the RFS.

The Energy Policy Act was preceded by bans on the use of methyl tertiary butyl ether (MTBE) in some states such as California after 2000. Given that ethanol was (and continues to be) the only alternative to MTBE, these bans effectively represented a state-level mandate for the use of ethanol. Indeed the Energy Policy Act by not granting liability waivers to users of MTBE, effectively created a nationwide ban on the use of the MTBE in producing finished motor gasoline. While it is conceivable that these bans contributed to expectations of rising ethanol prices in 2005, in addition to the Energy Policy Act, the fact that the spot price of ethanol coincided with the breakeven price in April 2005 argues against such a link. If there had been an important anticipatory component in the spot price of ethanol at that point, one would have expected the spot price to exceed the breakeven price. Thus, it seems implausible that the rise in ethanol price expectations in late 2005 may be attributed simply to the MTBE ban. If this explanation were correct, ethanol price expectations should have risen by April 2005 already rather than only in late 2005. ${ }^{11}$

More generally, our evidence suggests that market participants did not anticipate the Energy Policy Act before it was passed by the House of Representatives. ${ }^{12}$ As Figure 7 shows, the bulk of the effect on expectations occurred only after the RFS had been enacted. The peak

\footnotetext{
${ }^{11}$ It may seem that an alternative identification strategy would have involved tracing shifts in ethanol price expectations to policy shifts at the state level. That strategy is not feasible, however, because ethanol price expectations data are not available prior to September 2005. Thus, our sample excludes the dates at which the earlier state-level MTBE bans were introduced. In any case, most U.S. states are too small for these policy changes to have a material effect on aggregate ethanol price expectations.

${ }^{12}$ This result is consistent with the observation that the last energy bill had been passed in 1992 and there had been several unsuccessful attempts between 1992 and 2005 to pass additional energy bills.
} 
response at all horizons occurred only in June 2006, at which point the effect of imposing the RFS on expectations ranged from almost $\$ 1.50$ at short horizons to $\$ 1.18$ at the 12 -month horizon. By the end of 2006 at the latest, this effect had vanished. Although ethanol price expectations at the end of 2006 were still higher than in April 2005 by at least 70 cents, much of the surge in expectations in 2006 remained temporary. This fact is of some interest in that Carter, Rausser, and Smith (2017), when analyzing the corn market, interpreted the introduction of the RFS regulation as a permanent shift in longer-run price expectations for corn and implicitly for ethanol. Although it is reasonable to presume that the RFS represents a persistent upward shift in the expected demand for ethanol, price expectations depend on both expected demand and expected supply (see Kilian and Murphy 2014). How persistently ethanol price expectations increase thus depends on the market's assessment of the future corn and ethanol supply response to the RFS. If we take the April 2005 price as the baseline, then Figure 8 is consistent with a persistent increase in ethanol price expectations, but the persistent component is only about one third of the overall increase in expectations in 2005-06.

It has been argued that the RFS targets ex post were not economically binding until perhaps late 2013. This observation does not imply, however, that ethanol price expectations could not have increased in response to the introduction of RFS standards. The temporary increase in ethanol price expectations in Figure 8 in late 2005 and in early 2006 is consistent with the view that the market was initially concerned with shortages in the ethanol market, even if these shortages did not materialize. One possible reason is that higher storage demand for ethanol in response to higher price expectations raised the spot price of ethanol and hence stimulated ethanol production. It is also conceivable that the market's ex ante perceptions of the RFS simply differed from the ex post outcome or that the market initially was uncertain about 
the effects of this policy shift, but that this uncertainty vanished over time. The latter interpretation would be equally consistent with the observed decline in ethanol price expectations in 2006 in Figure 8.

The counterfactual in Figure 7 takes as given the breakeven price (and implicitly the price of corn). As we observed, the cost of corn and the breakeven price started to increase only in late 2006 (see Figure 5). To the extent that the imposition of the RFS changed the cost of corn and hence the breakeven price, this counterfactual underestimates the effect of the RFS on ethanol price expectations in late 2006 and early 2007. One explanation of the increase in corn prices starting in late 2006 is increased global demand for corn both as an ingredient in food production and as animal feed. For example, Baumeister and Kilian (2014) emphasize increased demand for corn from China in response to rising Chinese demand for pork and poultry. An alternative explanation of this increase would be increased flow demand for corn driven by the RFS, as U.S. ethanol production expanded. A third explanation could be increased storage demand for corn associated with the RFS. The question is why this shift in storage demand did not occur earlier, given that the RFS mandate was predictable. One would have to argue that in 2005 and throughout much of 2006 the corn market was able to easily accommodate the needs of the biofuel industry, until rising RFS mandates for 2007 created expectations of a shortage in late 2006. These explanations are not mutually exclusive and it would be a mistake to automatically attribute the approximately $\$ 0.70$ increase in the breakeven price by early 2007 to the RFS.

\subsubsection{The 2007 Energy Independence and Security Act}

There is no evidence that in 2007 ethanol price expectations increased materially in anticipation of the new and higher RFS mandates imposed by the Energy Independence and Security Act beyond what would have been expected given the breakeven price. This result is in sharp 
contrast to the evidence for the 2005 Energy Policy Act. Nor is there evidence that higher RFS mandates in early 2008 were associated with increased ethanol price expectations relative to the counterfactual. In fact, the breakeven price as well remained largely stable following the passing of the Energy Independence and Security Act by the House (see Figure 5). Only in 2008 is there a sharp increase in the price of corn and in the breakeven price of ethanol. Our analysis does not allow us to disentangle how much of this corn price increase is explained by higher RFS mandates as opposed to higher global demand for corn from the farm and food industry. However, the sharp decline in the breakeven price and in the price of corn after mid-2008 suggests that this temporary corn price increase had less to do with the permanent changes to the RFS than with shifts in the global demand for food and animal feed.

The fact that the 2005 Energy Policy Act appears to have affected ethanol price expectations, whereas the 2007 Energy Independence and Security Act apparently did not, is not an accident. A likely explanation is that, when the latter was discussed and implemented, existing capacity for ethanol production and blending was already adequate to reach the mandated targets.

\subsection{Implications for the Storage Demand for Ethanol}

Policies such as the RFS increase the flow demand for ethanol and hence are expected to raise the price of ethanol and the price of corn, from which ethanol is produced. They may also increase the storage demand for ethanol in anticipation of rising ethanol (and hence corn) prices. The latter effect may help explain the sharp increase in the market price of ethanol starting in 2005, even before the implementation of the RFS.

For this explanation to be valid it is not enough, however, for ethanol price expectations to increase. A necessary condition for a shift in expectations to cause increased storage demand 
for ethanol (and for related commodities such as corn) is that the long-term expectation must exceed the short-term expectation because, if the price is expected to increase only temporarily, producers would rather draw down inventories than build additional inventories.

This question may be addressed directly given our estimates of ethanol price expectations at different horizons. Figure 9 plots the term structure of ethanol price expectations. There is clear evidence that in 2005 longer-term price expectations exceeded short-term price expectations. For example, the 12-month expectation of the price of ethanol exceeded the 3month expectation in September 2005 by 52 cents per gallon, consistent with an important role for storage demand in 2005 prior to the imposition of the RFS.

Another, if much smaller, episode of long-run ethanol price expectations exceeding shortrun expectations occurred in 2013. For example, the 12-month ethanol price expectation exceeded the 3-month expectation by 37 cents by mid-2013, only to revert back to average levels after the EPA clarifies its policy stance with the August 2013 EPA announcement signaling lower RFS mandates (and hence lower demand for ethanol). ${ }^{13}$ This pattern is consistent with the view that the market expected a shortage of ethanol in 2014, if the RFS mandates had remained at their original levels.

We conclude that only for 2005 and to a lesser extent for 2013 is there convincing evidence in support of a role of storage demand in driving up the spot price of ethanol. This conclusion is consistent with the evidence in Figure 4 that not all of the increase in ethanol prices after the imposition of the RFS was anticipated. That figure indicated that the market was surprised by the extent of the ethanol price boom in 2006. For example, in September 2005, after

\footnotetext{
${ }^{13}$ Much of this increase in longer-run expectations relative to short-run expectations in early 2013 can be traced to a rising risk premium. Figure 1 suggested that policy uncertainty about how the EPA would deal with the blend wall temporarily raised the risk premium in the ethanol futures market by as much as 50 cents at longer horizons. This phenomenon largely explains the positive spike in 2013 in the term structure of expectations.
} 
the passing of the Energy Policy Act, the market underestimated the ethanol price increase in June 2006 by $\$ 1.14$ per gallon. Similarly, the market largely failed to anticipate the ethanol price increase following the Energy Independence and Security Act of late 2007. This evidence suggests that much of the increase in the price of ethanol in 2006 and beyond was actually driven by increased flow demand for ethanol.

\subsection{The Role of Corn Price Expectations}

It has been common in the recent literature to attribute surging corn prices to increased storage demand triggered by changes in biofuel policies. For example, Wright (2004) concluded that “the price jumps [in many food commodities] since 2005 are best explained by the new policies causing a sustained surge in demand for biofuels” (page 75), but his empirical analysis was informal and focused on the implicit market for grain calories rather than the market for corn. In contrast, Roberts and Schlenker (2013), using a formal econometric model allowing for forwardlooking behavior, attributed only about $20 \%$ of the corn price increases of 2005-08 to ethanol mandates, noting the importance of shifts in the global demand for food and animal feeds. Finally, based on an econometric model of the corn market, Carter, Rausser and Smith (2017) concluded that expectation shifts associated with biofuel policies caused a surge in corn prices. The common theme in these studies is that increases in the price of food commodities such as corn are attributed at least in part to rising corn price expectations (and implicitly ethanol price expectations) as a result of changes in biofuel policies such as the RFS.

Our analysis of how much the imposition of the RFS shifted ethanol price expectations in 2005-07 sheds new light on the empirical plausibility of these conclusions. On the one hand, the result that ethanol price expectations rose in 2005 and 2006 in response to the RFS is consistent with these earlier accounts, and so is our evidence that storage demand for ethanol rose as early 
as 2005. On the other hand, while expectations shifts associated with the RFS may have contributed to increases in the market price of ethanol in 2005 and 2006, the corresponding increase in the spot price of corn only started in late 2006, when the ethanol boom had already peaked and longer-run ethanol price expectations were declining (see Figure 10). Even without having any data on corn price expectations, this evidence allows us to conclude that the rise in ethanol price expectations triggered by the RFS did not coincide with a similar large rise in price expectations for corn. If it had, there would have been a shift in corn inventory demand and the price of corn would have increased much earlier than it actually did. Thus, our evidence suggests that the link between the ethanol and the corn market is less tight than commonly assumed in discussions of biofuel policies. If there is a link, then expectations in the corn market in late 2006 and in 2007 must have been backward-looking rather than forward-looking. Alternatively, the surge in the price of corn after late 2006 may simply reflect increased flow demand for corn.

This conclusion is consistent with tentative evidence from the corn futures market. Although there is no continuous monthly time series of corn futures prices, there are five observations for every year. Table 8 shows that, even ignoring the possible presence of a risk premium, these futures prices are a better proxy for the market expectation of the corn price than the current corn price. Especially at longer horizons, the gains in accuracy are striking. Figure 10, however, shows no evidence of an increase in the 12-month corn futures price in 2005 or in 2006 (except toward the end of the year), consistent with our economic reasoning. This result adds to the evidence that corn price expectations (and hence the storage demand for corn) do not move proportionately with ethanol price expectations (and storage demand), calling into question the interpretation in Wright (2014) and Carter, Rausser and Smith (2017). 
It is useful to contrast this result with the data for physical corn inventories. Although there are no data on ethanol stocks before late 2010, the U.S. Department of Agriculture provides quarterly data that allow the construction of the year-on-year change in corn stocks. Interpreting these data is complicated by the fact that a rise in corn inventories, for example, may reflect a higher flow supply of corn, a lower flow demand for corn, or higher storage demand for corn reflecting expectations of rising corn prices (see Fattouh et al. 2013, Kilian and Murphy 2014). The data show a substantial increase in year-on-year corn stocks in the first two quarters of 2005, but not in the last two quarters (see Figure 11). Given the evolution of corn spot and futures prices, it seems likely that this increase had more to do with flow demand and/or flow supply shocks in the corn market than with shifts in price expectations caused by the RFS. This conclusion is reinforced by the fact that the increase in corn inventories began in 2004, well before the House passed the Energy Policy Act.

The divergence of corn and ethanol prices prior to late 2006 does not mean that there has not been a close relationship between 12-month ethanol price expectations and 12-month corn price expectations in recent years. Figure 12 presents a simple thought experiment in which we approximate the expected price of ethanol by the expected change in the breakeven price of producing ethanol, obtained by subtracting indirect subsidies for ethanol production from the total cost of producing ethanol and expressed in dollars per gallon. The expected breakeven price is approximated by assuming that all production costs but the cost of corn remain unchanged. The cost of corn can be shown to account for up to $85 \%$ of the total cost of producing ethanol. The expected price of corn is proxied for by the corn futures price, which for this purpose is linearly interpolated.

This approach allows us to write the expected breakeven price at horizon $h$ as 


$$
E_{t}\left(B E P_{t+h}\right)=T C_{t}\left(1+\left(\frac{\text { corn cost }}{T C_{t}}\right) \frac{\left(F_{t}^{h, \text { corn }}-S_{t}^{\text {corn }}\right)}{S_{t}^{\text {corn }}}\right)-T I S_{t} \text {, }
$$

where all prices have been expressed in dollars/gallon, $T C_{t}$ denotes the total cost per gallon of ethanol, $F_{t}^{h, c o r n}$ is the linearly interpolated futures price, which is treated as a proxy for the expected price of corn, $S_{t}^{c o r n}$ is proxied for by the producer price of corn, the expected percentage change in the price of corn is weighted by the share of corn costs in the total cost of producing ethanol, and $T I S_{t}$ stands for the total indirect subsidies for ethanol production.

The upper panel of Figure 12 shows that even this crude approximation provides an excellent approximation to ethanol price expectations after 2006, except during 2008 and 2013. Although we cannot estimate the risk premium in the corn futures market, given the data limitations, a reasonable presumption, given the premise of integrated corn and ethanol markets in the existing literature, is that the risk premium in the corn futures market is similar to the risk premium in the ethanol market, as shown in Figure 1. The lower panel of Figure 12 illustrates that adjusting the corn futures price by the risk premium under the additional working assumption that the corn and ethanol risk premia are identical, results in near perfect comovement of corn and ethanol price expectations at the 12-month horizons after 2006. Of course, the degree of comovement is somewhat weaker at shorter horizons.

There is another way of interpreting this exercise. If we are willing to abstract from any direct effects of changes to the RFS on corn price expectations, the expected breakeven price in Figure 12 could also be interpreted as an alternative to the baseline counterfactual in section 5.1. To the extent that there is feedback from changes to the RFS to the expectation of the price of corn, this alternative counterfactual may still be viewed as a lower bound on causal effect of the RFS. Under this interpretation, the lower panel of Figure 12 confirms the earlier conclusion that 
the RFS caused the expected price of ethanol to increase starting in 2005 by between $\$ 0.31$ and \$0.47. The peak effect in 2006 can be bounded at $\$ 0.96$, compared with $\$ 1.18$ in the baseline counterfactual in Figure 8.

Although the assumption that the corn risk premium mirrors the ethanol risk premium is appealing after 2006, it is less so at the beginning of the sample. If we abstract from the risk premium in 2005 and 2006, based on the upper panel of Figure 12 we may conclude that the RFS caused corn price expectations to increase by between $\$ 0.41$ and $\$ 1.15$ in 2005 , reaching a peak of \$1.11 in 2006, much like in the baseline counterfactual. Either way, we have strong evidence that the imposition of the RFS shifted ethanol price expectations by at least \$1 in 2006 and somewhat less in 2005 in anticipation of the RFS, even ignoring any effects the RFS might have had on the cost of corn used in ethanol production.

\section{Conclusion}

Answering the question of how policy interventions affect market prices is complicated by the fact that shifts in policy can typically be anticipated. Legislative action follows a slow process, and changes in policy are often announced well before their implementation. The changes to U.S. biofuel policies after 2005 are a case in point. It is well understood that the response of the price of ethanol (and the price of related commodities such as corn) to shifts in biofuel policies operates in part through market expectations, yet it has proved difficult to measure these expectations to date and to directly confront these views with the data (see Wright 2014; Baumeister and Kilian 2014; Carter, Rausser and Smith 2017).

We utilized a recently proposed methodology to quantify the market's expectations of the prices of ethanol, unfinished motor gasoline and Brent crude oil at horizons from three months to one year, noting that the structure of the corn futures price data prevents a similar analysis of 
corn price expectations. We quantified the extent to which price changes were anticipated by the market and the extent to which they were unanticipated. We also quantified the extent to which the risk premium in these markets has evolved in response to shifts in policy uncertainty and possibly to changes in financial investor participation. We provided evidence against the view that the increased financialization of commodity markets has created an integrated market for crude oil, unfinished motor gasoline and ethanol. In particular, ethanol prices were shown to behave quite differently from the prices for oil and gasoline.

Policies such as the RFS increase the flow demand for ethanol and hence are expected to raise the price of ethanol and the price of corn, from which ethanol is produced. They may also increase the storage demand for ethanol (and for corn) in anticipation of rising ethanol (and hence corn) prices. The latter effect may help explain the sharp increase in the producer price of ethanol starting in 2005, even before the implementation of the RFS. Our analysis is the first to assess this question empirically. A necessary condition for a shift in expectations to raise the storage demand for ethanol (and for related commodities such as corn) is that the long-term expectation exceeds the short-term expectation because, if the price is expected to increase only temporarily, producers would rather draw down inventories than build additional inventories. We confirmed that the 12-month expectation of the price of ethanol exceeded the 3-month expectation in September 2005, for example, by 52 cents per gallon prior to the imposition of the RFS, consistent with an important role for storage demand in 2005.

Another, if much smaller, episode of higher long-run ethanol price expectations occurred in 2013. We showed that the 12-month ethanol price expectation had risen above the 3-month expectation by 37 cents by mid-2013, only to revert back to average levels after the EPA clarified its policy stance after the August 2013 EPA announcement signaling lower RFS 
mandates (and hence lower demand for ethanol). Some of the increase in longer-run expectations in early 2013 coincided with a rising longer-run risk premium. We provided evidence that policy uncertainty about how the EPA would deal with the blend wall prior to August 2013 raised the risk premium in the ethanol futures market by as much as 50 cents at longer horizons.

Not all of the increase in ethanol prices after the imposition of the RFS was anticipated. We showed that the market was surprised by the extent of the ethanol price boom in 2006. For example, in September 2005, after the passing of the Energy Policy Act, the market underestimated the ethanol price increase in June 2006 by $\$ 1.14$ per gallon. Similarly, the market largely failed to anticipate the ethanol price increase following the Energy Independence and Security Act of late 2007.

Assessing the causal effect of the RFS on expectations is difficult. We provided a baseline counterfactual that suggested that the RFS may have raised ethanol price expectations by as much $\$ 1.45$ at the 3-month horizons and $\$ 1.18$ at the 12 -month horizons and that this effect may have started as early as April 2005, but continued to grow after the implementation of the RFS had started in 2006. This baseline counterfactual abstracted from any effects the RFS might have had on the cost of producing ethanol. The evidence that the RFS caused a large shift in ethanol price expectations in 2005-06 is strong, and the approximate magnitude of this effect was also corroborated by an alternative counterfactual. In contrast, there is no conclusive evidence of changes to the RFS having increased longer-run ethanol price expectations after 2007, consistent with the view that the ethanol-producing capacity was more than adequate to meet RFS targets at the time.

Finally, although we provided evidence that the expectations shifts associated with the RFS contributed to increases in the market price of ethanol in 2005 and 2006, this is not the case 
for corn prices. The corresponding increase in corn prices only started in late 2006, when the ethanol boom had already peaked and longer-run ethanol price expectations were declining. It does not appear to be the case that the rise in ethanol price expectations triggered by the RFS coincided with a similar rise in price expectations for corn. If it had, there would have been a shift in corn inventory demand and the price of corn would have increased much earlier than it actually did. Our evidence thus suggests that the link between the ethanol market and the corn market is less tight than commonly assumed in discussions of biofuel policies. An alternative explanation is that the surge in the spot price of corn after late 2006 may simply have reflected increased flow demand for corn, caused in part by the RFS, but also by growing global demand for corn as food and as animal feed.

\section{References:}

Abbott, P. (2014), “Biofuels, Binding Constraints, and Agricultural Commodity Price Volatility,” in: Chavas, J.P., Hummels, D., and B. Wright, The Economics of Food Price Volatility, National Bureau of Economic Research, University of Chicago Press, 91-134.

Anderson, S.T., R. Kellogg, and J.M. Sallee (2013), “What Do Consumers Believe about Future Gasoline Prices?” Journal of Environmental Economics and Management, 66, 383-403.

Baumeister, C., and L. Kilian (2014), “Do Oil Price Increases Cause Higher Food Prices?” Economic Policy, 80, 691-747.

Baumeister, C., and L. Kilian (2016a), “A General Approach to Recovering Market Expectations from Futures Prices with an Application to Crude Oil,” manuscript, University of Michigan.

Baumeister, C., and L. Kilian (2016b), “Understanding the Decline in the Price of Oil since June 2014,” Journal of the Association of Environmental and Resource Economists, 3, 131- 
158.

Baumeister, C., and L. Kilian (2016c), "Forty Years of Oil Price Fluctuations: Why the Price of Oil May Still Surprise Us,” Journal of Economic Perspectives, 30, 139-160.

Baumeister, C., and L. Kilian (2017), "Lower Oil Prices and the U.S. Economy: Is This Time Different?” Brookings Papers on Economic Activity, Fall 2016, 287-336.

Baumeister, C., Kilian, L., and T.K. Lee (2017), “Inside the Crystal Ball: New Approaches to Predicting the Gasoline Price at the Pump,” Journal of Applied Econometrics, 32, 275295.

Bielen, D.A., Newell, R.G., and W.A. Pizer (2016), "Who Did the Ethanol Tax Credit Benefit? An Event Analysis of Subsidy Incidence,” NBER Working Paper No. 21968.

Borenstein, S., and R. Kellogg (2014), “The Incidence of an Oil Glut: Who Benefits from Cheap Crude Oil in the Midwest?” Energy Journal, 35, 15-33.

Borenstein, S., and A. Shepard (2002), “Sticky Prices, Inventories, and Market Power in Wholesale Gasoline Markets,” RAND Journal of Economics, 33, 116-139.

Büyükşahin, B., Haigh, M.S., and M.A. Robe (2010). “Commodities and Equities: Ever a 'Market of One'?” Journal of Alternative Investments, 12, 76-95.

Büyükşahin, B., and M.A. Robe (2014), “Speculators, Commodities, and Cross-Market Linkages,” Journal of International Money and Finance, 42, 38-70.

Carter, C.A., Rausser, G.C., and A. Smith (2017), “Commodity Storage and the Market Effects of Biofuel Policies,” forthcoming: American Journal of Agricultural Economics.

Clark, T.E., and K.D. West (2007), “Approximately Normal Tests for Equal Predictive Accuracy in Nested Models,” Journal of Econometrics, 138, 291-311.

Coglianese, J., Davis, L.W., Kilian, L. and J.H. Stock (2017), “Anticipation, Tax Avoidance, 
and the Price Elasticity of Gasoline Demand,” Journal of Applied Econometrics, 32, 115.

Diebold, F.X., and R. Mariano (1995), “Comparing Predictive Accuracy,” Journal of Business and Economic Statistics, 13, 253-263.

Environmental Protection Agency (2007), "Regulation of Fuels and Fuel Additives: Renewable Fuel Standard Program; Final Rule,” Federal Register, 72(83), 23900-24014.

Fattouh, B., Kilian, L., and L. Mahadeva (2013), “The Role of Speculation in Oil Markets: What Have We Learned So Far?” Energy Journal, 34, 7-33.

Gilbert, R., and J. Hastings (2005), "Market Power, Vertical Integration and the Wholesale Price of Gasoline,” Journal of Industrial Economics, 53, 469-492.

Hamilton, J.D., and J.C. Wu (2014), “Risk Premia in Crude Oil Futures Prices,” Journal of International Money and Finance, 42, 9-37.

Hofstrand, D. (2016), “Tracking Ethanol Profitability,” Ag Decision Maker, Iowa State University Extension and Outreach, http://www.extension.iastate.edu/agdm/refirst.html.

Kilian, L. (2010), "Explaining Fluctuations in U.S. Gasoline Prices: A Joint Model of the Global Crude Oil Market and the U.S. Retail Gasoline Market,” Energy Journal, 31, 87-104.

Kilian, L. (2016a), “The Impact of the Shale Oil Revolution on U.S. Oil and Gas Prices,” Review of Environmental Economics and Policy, 10(2), 185-205.

Kilian, L. (2016b), "The Impact of the Fracking Boom on Arab Oil Producers,” manuscript, University of Michigan.

Kilian, L., and D.P. Murphy (2014), "The Role of Inventories and Speculative Trading in the Global Market for Crude Oil,” Journal of Applied Econometrics, 29, 454-478.

Mallory, M., Irwin, S., and D. Hayes (2012), “How Market Efficiency and the Theory of 
Storage Link Corn and Ethanol Markets,” Energy Economics, 34, 2157-2166.

Roberts, M.J., and W. Schlenker (2013), "Identifying Demand and Supply Elasticities of Agricultural Commodities: Implications for the U.S. Ethanol Mandate,” American Economic Review, 103, 2265-2295.

Salvo, A. and C. Huse (2011), "Is Arbitrage Tying the Price of Ethanol to that of Gasoline? Evidence from the Uptake of Flexible Fuel Technology,” Energy Journal, 32, 119-148.

Serra, T., Zilberman, D., Gil, J.M., and B.K. Goodwin (2011), “Nonlinearities in the U.S. CornEthanol-Oil-Gasoline Price System,” Agricultural Economics, 42, 35-45.

Silvennoinen, A., and S. Thorp (2013), "Financialization, Crisis, and Commodity Correlation Dynamics,” Journal of International Financial Markets, Institutions and Money, 24, 4265.

Stock, J.H. (2015), “The Renewable Fuel Standard: A Path Forward,” Center on Global Energy Policy, Columbia University.

Sweeney, R.L. (2015), “Environmental Regulation, Imperfect Competition and Market Spillovers: The Impact of the 1990 Clean Air Act Amendments on the U.S. Oil Refining Industry,” manuscript, Harvard University.

Tang, K., and W. Xiong (2012), “Index Investment and Financialization of Commodities,” Financial Analysts Journal, 68, 54-74.

U.S. Energy Information Administration (2013), "What Caused the Run-up in Ethanol RIN Prices during Early 2013?” June 13.

Wright, B. (2014), “Global Biofuels: Key to the Puzzle of Grain Market Behavior,” Journal of Economic Perspectives, 28, 73-98. 
Table 1: U.S. Legislative Changes Regarding Renewable Fuel

\begin{tabular}{|c|c|c|c|}
\hline \multicolumn{2}{|l|}{ Proposed } & \multicolumn{2}{|l|}{ Enacted } \\
\hline 04/18/05 & $\begin{array}{l}\text { Original version of bill passed in } \\
\text { House of Representatives }\end{array}$ & $\begin{array}{l}\text { 08/08/05 } \\
\text { (effective } \\
01 / 01 / 06 \text { ) }\end{array}$ & $\begin{array}{l}\text { Energy Policy Act signed into } \\
\text { law. EPA targets for RFS: } \\
4.0 \text { billion gallons in } 2006 \\
4.7 \text { billion gallons in } 2007 \\
5.4 \text { billion gallons in } 2008 \\
6.1 \text { billion gallons in } 2009 \\
6.8 \text { billion gallons in } 2010 \\
7.4 \text { billion gallons in } 2011 \\
7.5 \text { billion gallons in } 2012 \\
\text { Targets beyond } 2012 \text { to be } \\
\text { determined by EPA. }\end{array}$ \\
\hline $01 / 18 / 07$ & $\begin{array}{l}\text { Original version of bill passed in } \\
\text { the House of Representatives }\end{array}$ & $\begin{array}{l}12 / 19 / 07 \\
\text { (effective } \\
01 / 01 / 08 \text { ) }\end{array}$ & $\begin{array}{l}\text { Energy Independence and } \\
\text { Security Act of } 2007 \text { signed into } \\
\text { law, raising the RFS targets: } \\
9.00 \text { billion gallons in } 2008 \\
11.10 \text { billion gallons in } 2009 \\
12.95 \text { billion gallons in } 2010 \\
13.95 \text { billion gallons in } 2011 \\
15.20 \text { billion gallons in } 2012 \\
16.55 \text { billion gallons in } 2013 \\
18.15 \text { billion gallons in } 2014 \\
20.50 \text { billion gallons in } 2015 \\
22.25 \text { billion gallons in } 2016 \\
\ldots \\
36.00 \text { billion gallons in } 2022 \\
\text { Targets beyond } 2022 \text { to be } \\
\text { determined by EPA. These } \\
\text { targets were implemented by the } \\
\text { EPA as planned until end of } 2013\end{array}$ \\
\hline 02/07/13 & $\begin{array}{l}\text { EPA proposal for } 2013 \text { signals } \\
\text { possible shortage of RINs in } \\
2014\end{array}$ & $08 / 15 / 13$ & $\begin{array}{l}\text { Final EPA rule for } 2013 \text { signals } \\
\text { that RFS for } 2014 \text { may have to be } \\
\text { lowered }\end{array}$ \\
\hline $\begin{array}{l}11 / 29 / 13 \\
\text { (leaked to press } \\
\text { in October 2013) }\end{array}$ & $\begin{array}{l}\text { EPA proposes to lower its target } \\
\text { for } 2014 \text { to } 15.21 \text { billion gallons } \\
\text { in recognition of the blend wall }\end{array}$ & $12 / 09 / 14$ & $\begin{array}{l}\text { No targets are issued for } 2014 \text { or } \\
\text { 2015. Deliberations continue. }\end{array}$ \\
\hline 06/10/15 & $\begin{array}{l}\text { EPA proposes new targets: } \\
15.93 \text { billion gallons in } 2014 \\
16.30 \text { billion gallons in } 2015 \\
17.40 \text { billion gallons in } 2016\end{array}$ & $11 / 30 / 15$ & $\begin{array}{l}\text { EPA issues new targets: } \\
16.28 \text { billion gallons in } 2014 \\
16.93 \text { billion gallons in } 2015 \\
18.11 \text { billion gallons in } 2016\end{array}$ \\
\hline
\end{tabular}

NOTES: The RFS mandates do not correspond to gallons of ethanol, but rather to ethanol-equivalent gallons of renewable fuel. Inferring the ethanol consumption targets implied by the RFS mandates is not straightforward. We therefore focus on changes in the broader RFS mandates, which have been the primary focus of the public debate and press coverage. 
Table 2. Predictive Accuracy of Alternative Measures of Brent Oil Price Expectations

\begin{tabular}{ccc}
\hline \hline & \multicolumn{2}{c}{ Evaluation period: 2005.1-2015.12 } \\
\cline { 2 - 3 } Horizon $h$ & & Risk-adjusted \\
3 & Brent futures & Brent futures \\
\hline 6 & 1.075 & $\mathbf{0 . 8 5 7}^{*}$ \\
9 & 1.035 & $\mathbf{0 . 7 8 1}^{*}$ \\
12 & $\mathbf{0 . 9 5 5}^{*}$ & $\mathbf{0 . 7 1 4}^{*}$ \\
\hline
\end{tabular}

NOTES: Risk adjustments involve adding the estimated risk premium from the HW model to the futures price. All MSPE ratios have been normalized relative to the monthly no-change forecast. Boldface indicates an improvement on the monthly no-change forecast. Statistically significant improvements test are marked using * (5\% significance level) and ${ }^{* *}(10 \%$ significance level). The underlying risk-premium estimates are based on the full sample. MSPE reductions are evaluated based on the tests of Diebold and Mariano (1995) and Clark and West (2007), as appropriate.

Table 3. Predictive Accuracy of Alternative Measures of Gasoline Price Expectations

\begin{tabular}{|c|c|c|c|c|c|}
\hline \multirow[b]{2}{*}{ Horizon $h$} & \multicolumn{2}{|c|}{ Evaluation period: 2005.1-2015.12 } & \multicolumn{3}{|c|}{ Evaluation period: 2006.2 - 2015.12} \\
\hline & $\begin{array}{l}\text { Gasoline } \\
\text { futures }\end{array}$ & $\begin{array}{r}\text { Risk-adjusted } \\
\text { gasoline futures }\end{array}$ & $\begin{array}{l}\text { Gasoline } \\
\text { futures }\end{array}$ & $\begin{array}{l}\text { Risk-adjusted } \\
\text { gasoline } \\
\text { futures }\end{array}$ & $\begin{array}{l}\text { Michigan Survey } \\
\text { of Consumers }\end{array}$ \\
\hline 3 & $\mathbf{0 . 8 0 7}^{*}$ & $0.719^{*}$ & - & - & - \\
\hline 6 & $0.810^{*}$ & $0.642^{*}$ & - & - & - \\
\hline 9 & $0.887^{*}$ & $0.658^{*}$ & - & - & - \\
\hline 12 & $0.888^{*}$ & $0.647^{*}$ & $0.896^{* *}$ & $0.648^{*}$ & 1.089 \\
\hline
\end{tabular}

NOTES: See Table 2. The survey gasoline price expectation is obtained by adding the median expected change in the retail price of gasoline in the Michigan Survey of Consumers to the spot price of unfinished motor gasoline (see Baumeister, Kilian and Lee 2017).

Table 4. Predictive Accuracy of Alternative Measures of Ethanol Price Expectations

\begin{tabular}{ccc}
\hline \hline & \multicolumn{2}{c}{ Evaluation period: 2005.9-2015.12 } \\
\cline { 2 - 3 } Horizon $h$ & Ethanol futures & $\begin{array}{c}\text { Risk-adjusted } \\
\text { ethanol futures }\end{array}$ \\
\hline 3 & $\mathbf{0 . 7 9 2}^{* *}$ & $\mathbf{0 . 6 8 5}^{*}$ \\
6 & $\mathbf{0 . 7 9 0}^{*}$ & $\mathbf{0 . 6 5 3}^{*}$ \\
9 & $\mathbf{0 . 8 0 5}^{*}$ & $\mathbf{0 . 5 9 3}^{*}$ \\
12 & $\mathbf{0 . 6 9 1}^{*}$ & $\mathbf{0 . 6 5 2}^{*}$ \\
\hline
\end{tabular}

NOTES: See Table 2. 
Table 5: Correlation Analysis for Risk Premia (Percent)

\begin{tabular}{cccc}
\hline Horizon & $\begin{array}{c}\text { Brent- } \\
\text { Unfinished Gasoline }\end{array}$ & $\begin{array}{c}\text { Brent- } \\
\text { Ethanol }\end{array}$ & $\begin{array}{c}\text { Unfinished Gasoline- } \\
\text { Ethanol }\end{array}$ \\
\hline 3 & 74.0 & 38.7 & 58.5 \\
6 & 83.3 & 53.1 & 53.1 \\
9 & 86.6 & 48.8 & 43.5 \\
12 & 89.1 & 47.1 & 41.1 \\
\hline
\end{tabular}

Source: Computations of the authors based on an adaptation of the term-structure model of Hamilton and Wu (2014).

Table 6: Correlation Analysis for Term Structure of Price Expectations (Percent)

\begin{tabular}{cccc}
\hline Horizon & $\begin{array}{c}\text { Brent- } \\
\text { Unfinished Gasoline }\end{array}$ & $\begin{array}{c}\text { Brent- } \\
\text { Ethanol }\end{array}$ & $\begin{array}{c}\text { Unfinished Gasoline- } \\
\text { Ethanol }\end{array}$ \\
\hline 3 & 64.7 & 32.4 & 41.6 \\
6 & 76.1 & 53.6 & 54.6 \\
9 & 85.1 & 62.5 & 62.2 \\
12 & 94.1 & 64.4 & 63.4 \\
\hline
\end{tabular}

Source: Computations of the authors based on an adaptation of the term-structure model of Hamilton and $\mathrm{Wu}$ (2014). The term structure is defined as the spread between the price expectation at a given horizon and the current spot price and represents the expected change in the price at that horizon.

Table 7: Correlation Analysis for Price Shocks (Percent)

\begin{tabular}{cccc}
\hline Horizon & $\begin{array}{c}\text { Brent- } \\
\text { Unfinished Gasoline }\end{array}$ & $\begin{array}{c}\text { Brent- } \\
\text { Ethanol }\end{array}$ & $\begin{array}{c}\text { Unfinished Gasoline- } \\
\text { Ethanol }\end{array}$ \\
\hline 3 & 93.9 & 49.3 & 50.6 \\
6 & 96.8 & 64.8 & 64.8 \\
9 & 96.8 & 79.5 & 77.2 \\
12 & 96.4 & 78.0 & 76.7 \\
\hline
\end{tabular}

Source: Computations of the authors based on an adaptation of the term-structure model of Hamilton and $\mathrm{Wu}$ (2014). A price shock is defined as the difference between the price expectation and the realization of the price.

Table 8: Predictive Accuracy of Corn Futures Prices

\begin{tabular}{cc}
\hline \hline & $\begin{array}{c}\text { Evaluation period: } \\
2005.1-2015.12\end{array}$ \\
\cline { 2 - 2 } Horizon $h$ & Corn futures \\
\hline 3 & $\mathbf{0 . 8 9 1}^{*}$ \\
6 & $\mathbf{0 . 7 7 0}^{*}$ \\
12 & $\mathbf{0 . 7 1 1}^{*}$ \\
\hline
\end{tabular}

NOTES: See Table 2. The corn futures prices are from Bloomberg and exist only for selected months. We evaluate the predictive accuracy of these prices against the no-change prediction for ethanol producer price from Hofstrand (2016). 
Figure 1: Risk Premium Estimates by Market and Horizon (U.S. Dollar/Gallon)

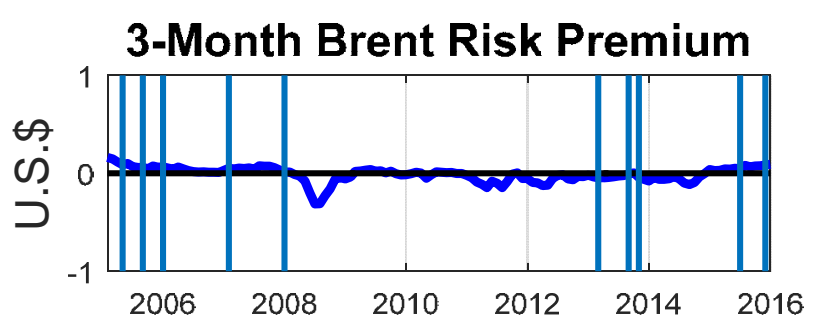

6-Month Brent Risk Premium

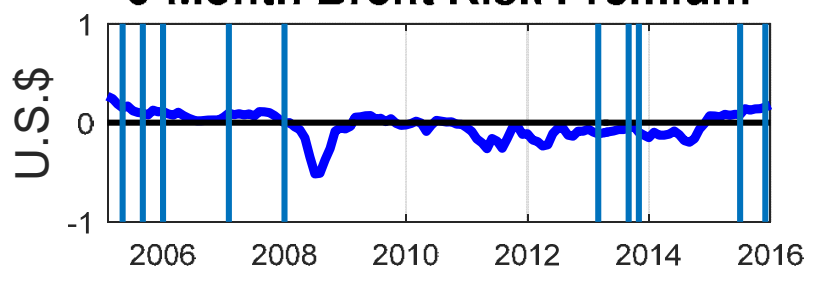

9-Month Brent Risk Premium

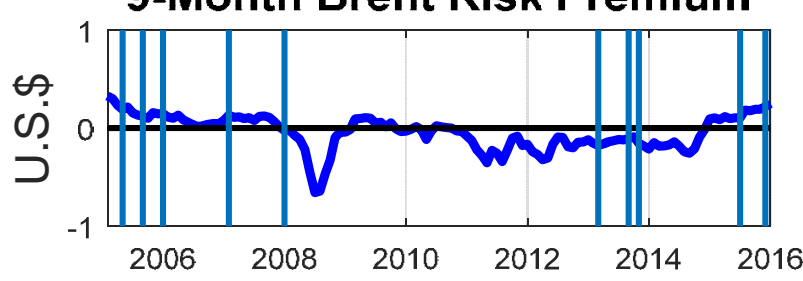

12-Month Brent Risk Premium

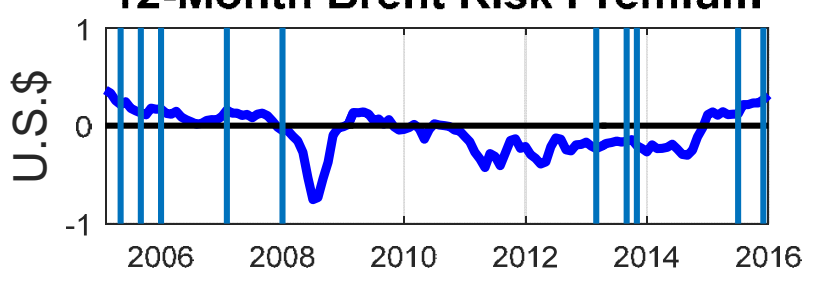

3-Month Unfinished Gasoline Risk Premium

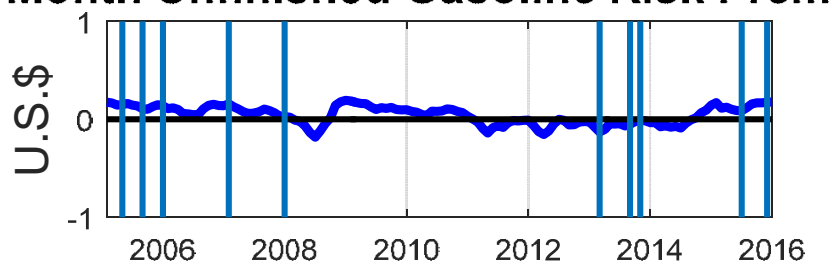

6-Month Unfinished Gasoline Risk Premium
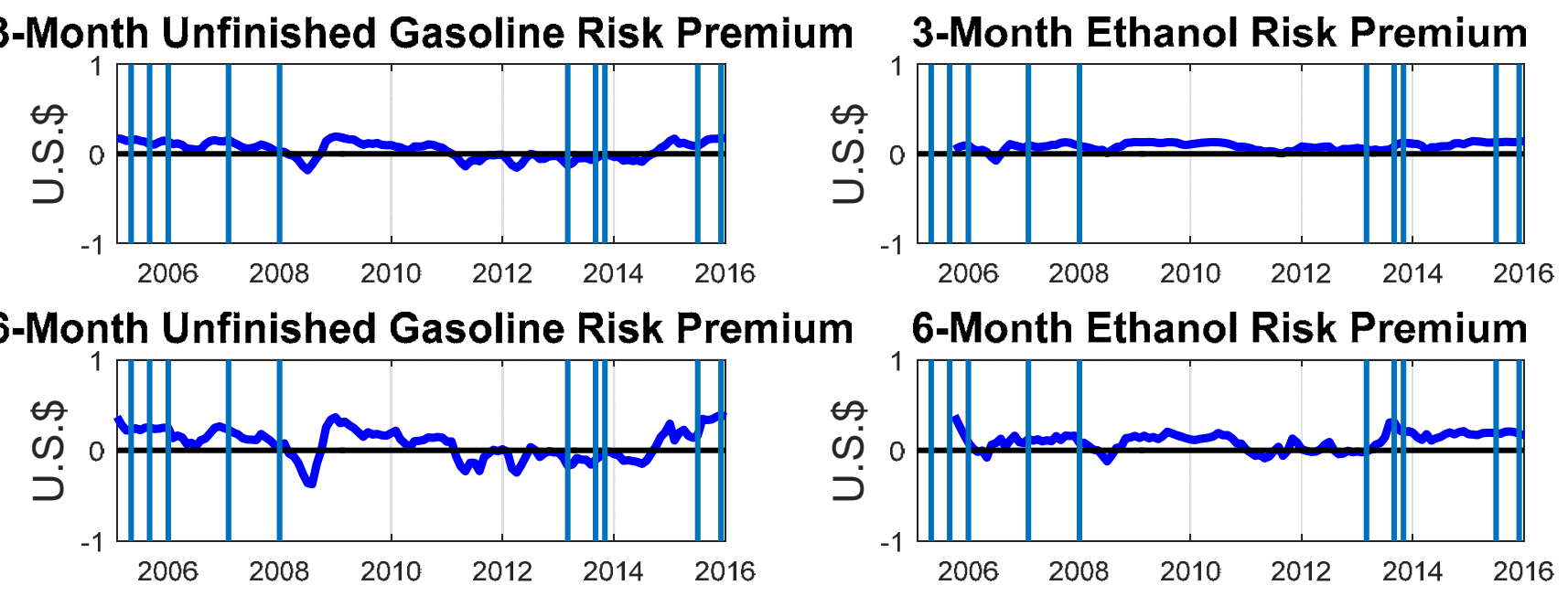

9-Month Unfinished Gasoline Risk Premium
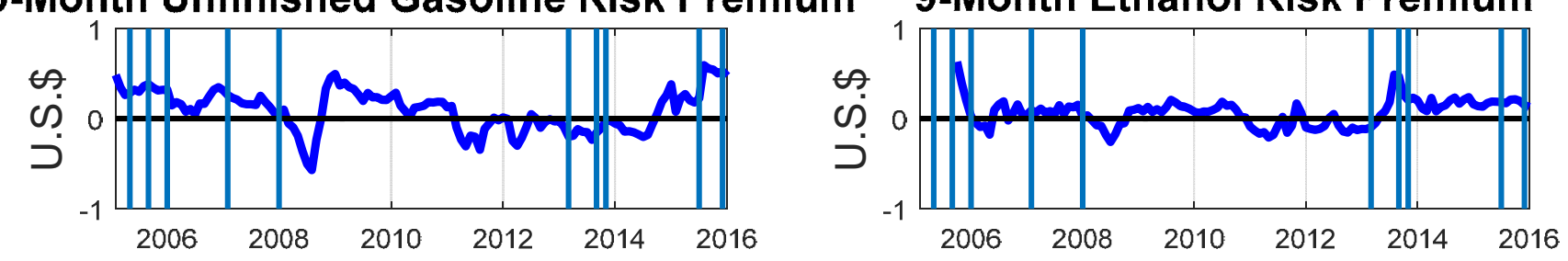

12-Month Unfinished Gasoline Risk Premium
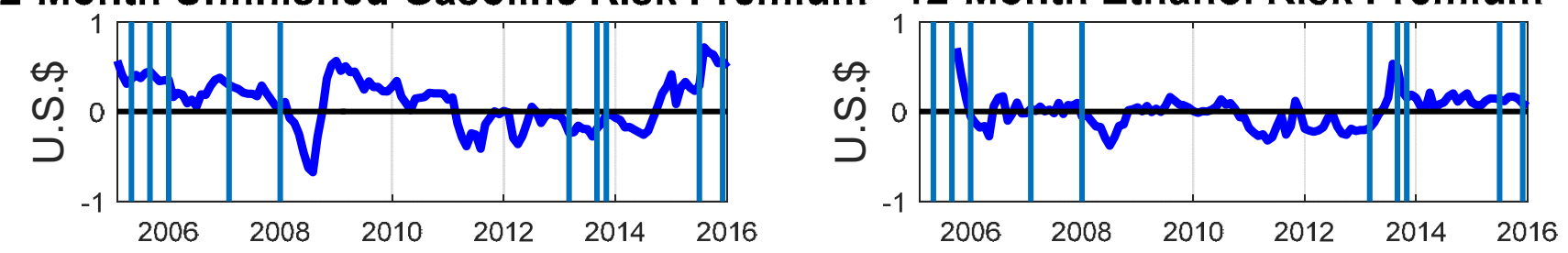

Source: Computations of the authors based on an adaptation of the term-structure model of Hamilton and Wu (2014). A positive risk premium, $R P_{t}^{h}, h=3,6,9,12$, indicates that the market expectation exceeds the futures price. The horizontal line represents date $t$. The vertical lines indicate dates of proposed and actual changes to the Renewable Fuel Standard, as described in Table 1. 
Figure 2: Expected Price by Market and Horizon (U.S. Dollar/Gallon)
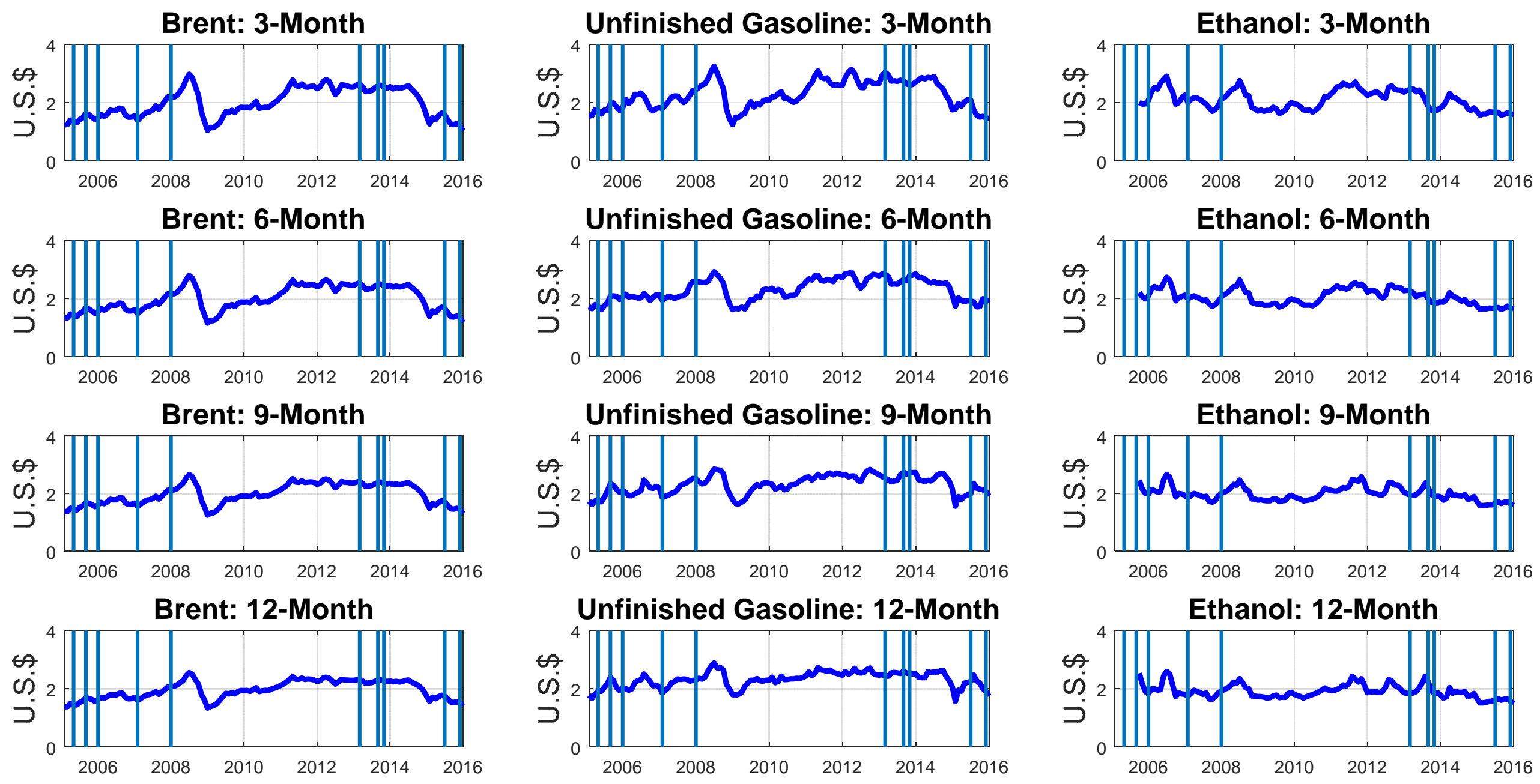

Source: The price expectations, $E_{t}\left(S_{t+h}\right), h=3,6,9,12$, are obtained by subtracting the risk premium in Figure 1 from the futures price. The horizontal line represents date $t$. The vertical lines indicate dates of proposed and actual changes to the Renewable Fuel Standard, as described in Table 1. 
Figure 3: Expected Price Changes by Market and Horizon (U.S. Dollar/Gallon)

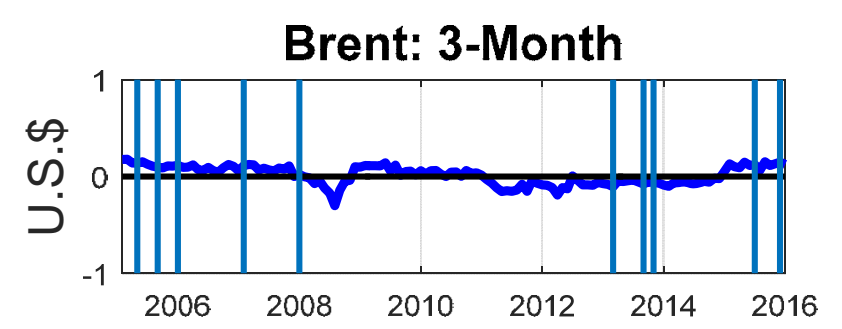

Brent: 6-Month

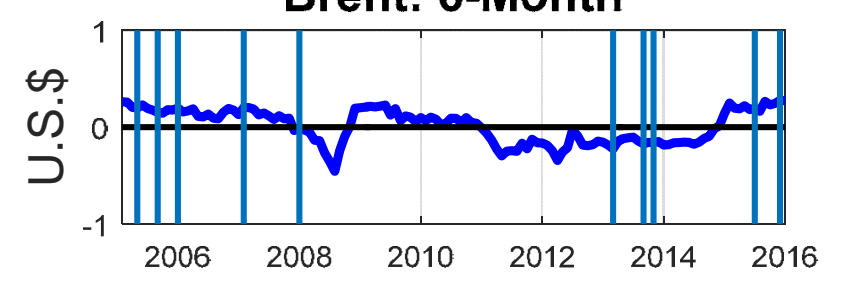

Brent: 9-Month

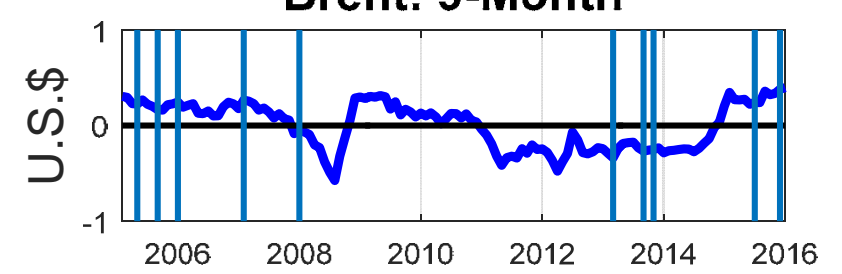

Brent: 12-Month

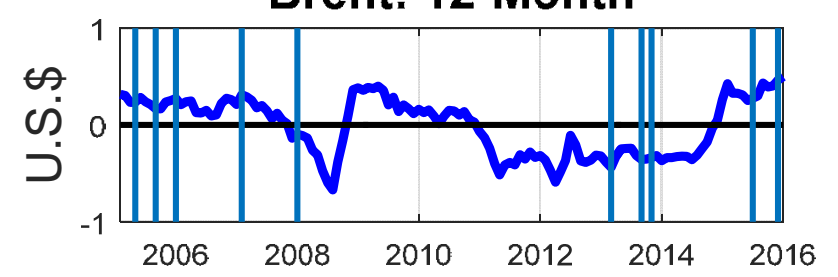

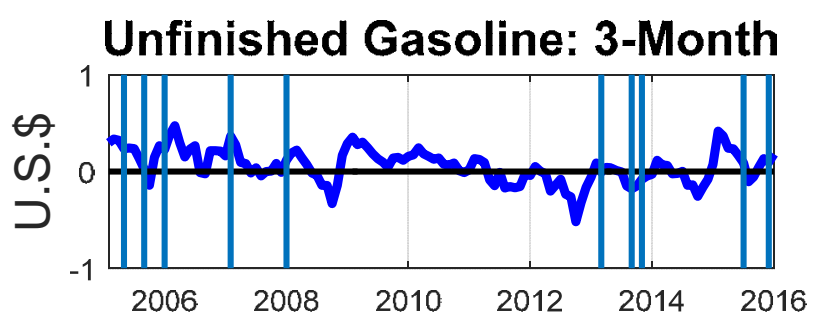

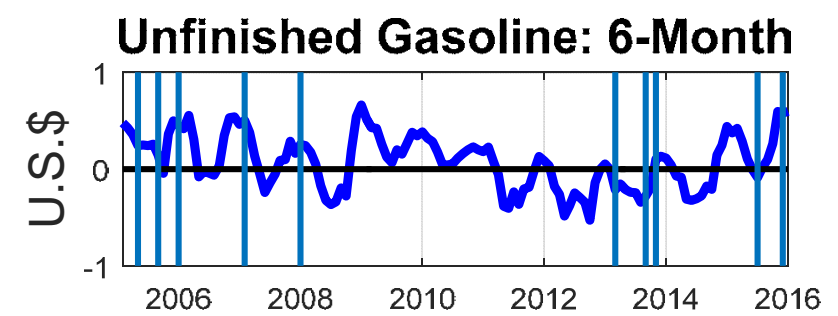

Unfinished Gasoline: 9-Month

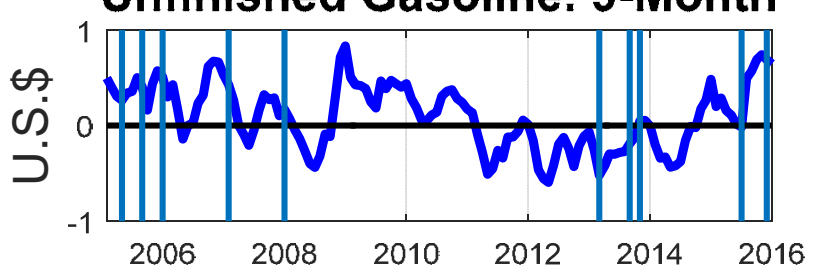

Unfinished Gasoline: 12-Month

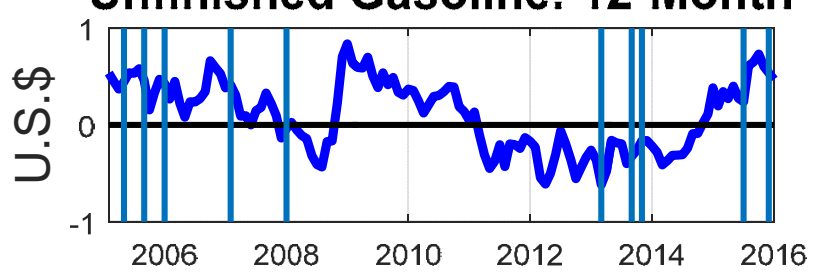

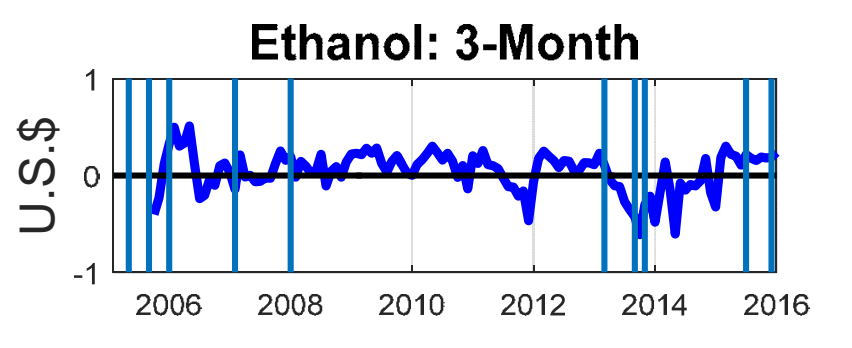

Ethanol: 6-Month
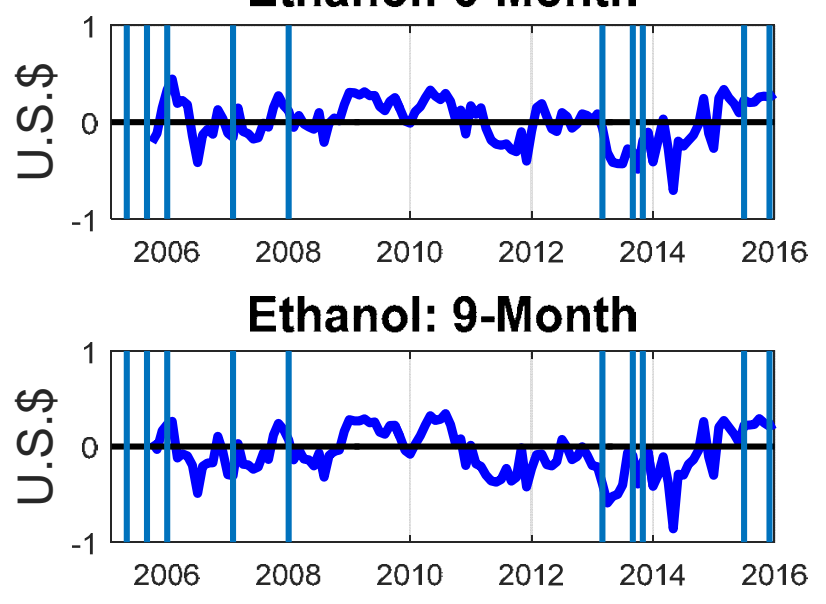

Ethanol: 12-Month

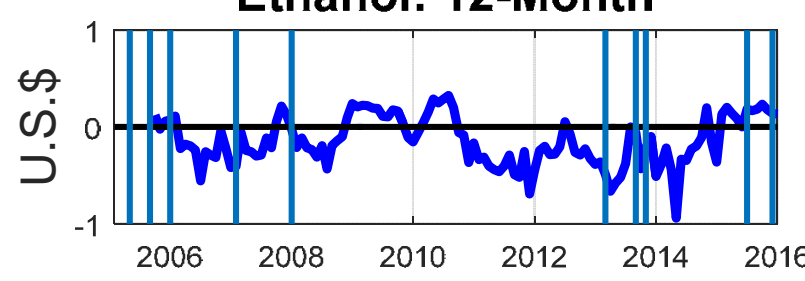

Source: The price expectations are obtained by subtracting the risk premium from the futures price. The expected price changes, $E_{t}\left(S_{t+h}\right)-S_{t}$, are constructed by subtracting the current spot price from the price expectation in Figure 2. The horizontal line represents date $t$. The vertical lines indicate dates of proposed and actual changes to the Renewable Fuel Standard, as described in Table 1. 
Figure 4: Unexpected Price Changes by Market and Horizon (U.S. Dollar/Gallon)

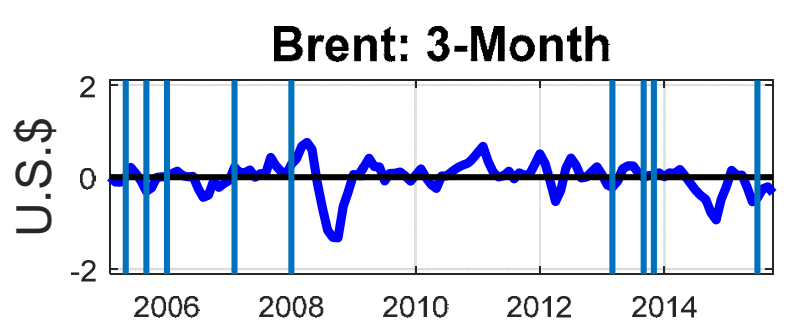

Brent: 6-Month

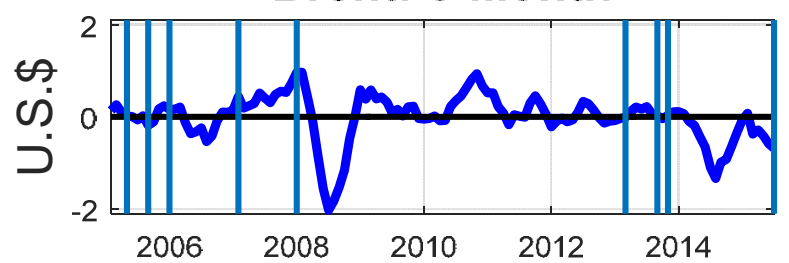

Brent: 9-Month

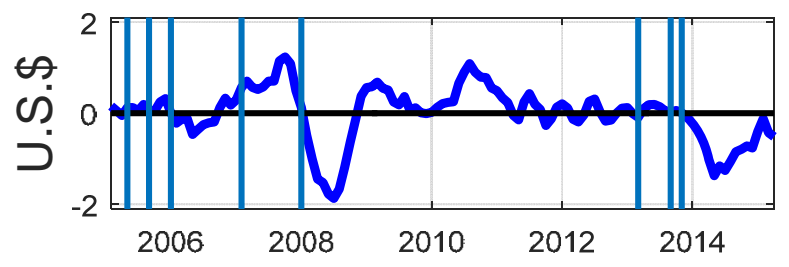

Brent: 12-Month

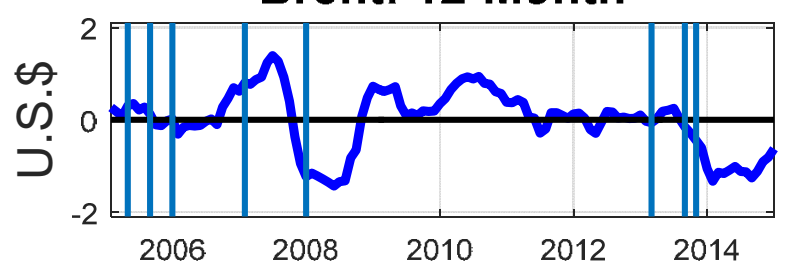

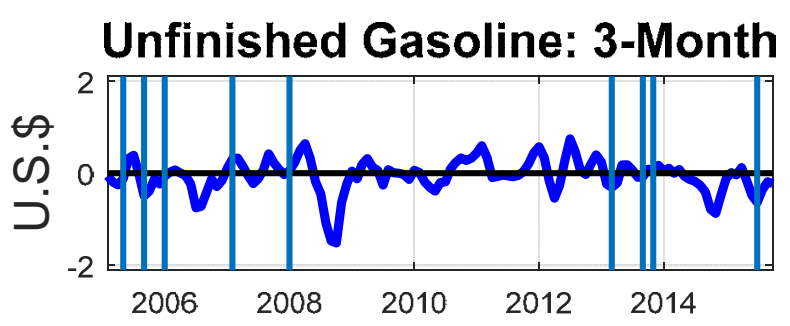

Unfinished Gasoline: 6-Month

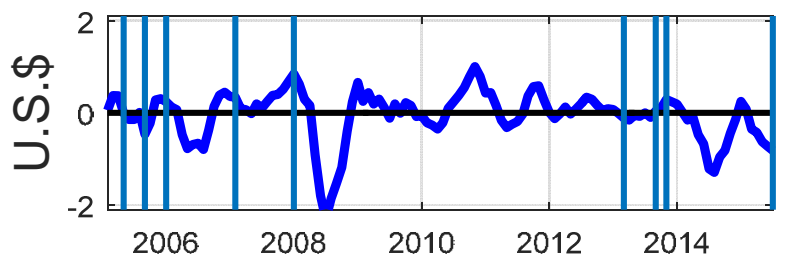

Unfinished Gasoline: 9-Month

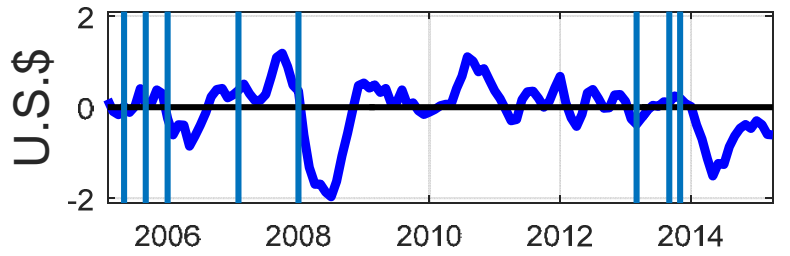

Unfinished Gasoline: 12-Month

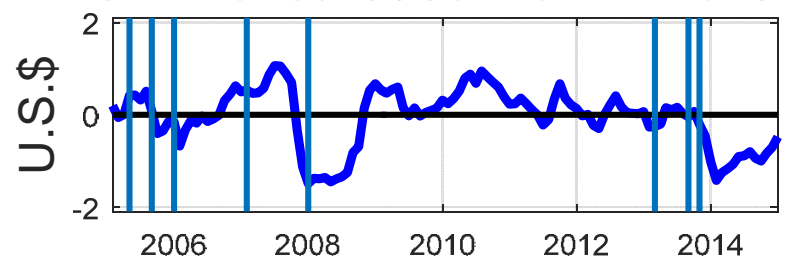

Ethanol: 3-Month

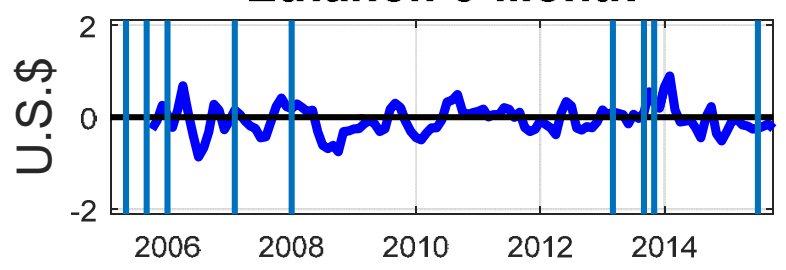

Ethanol: 6-Month

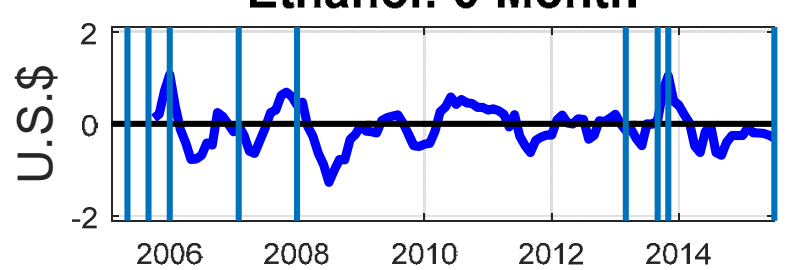

Ethanol: 9-Month

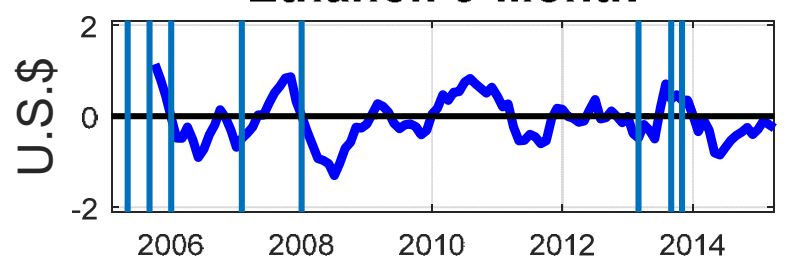

Ethanol: 12-Month

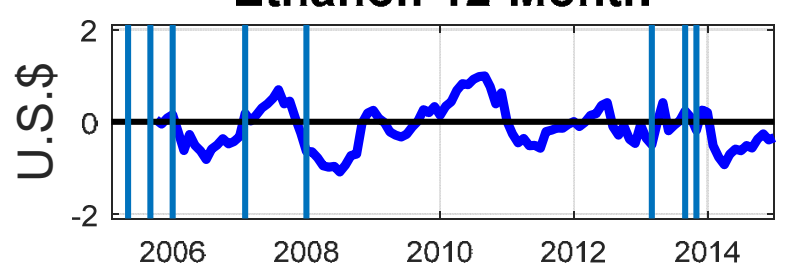

Source: The unexpected price changes (or price shocks), $S_{t+h}-E_{t}\left(S_{t+h}\right)$, are obtained by subtracting the price expectation in Figure 2 from the realization of the spot price. The horizontal line represents date $t$. The vertical lines indicate dates of proposed and actual changes to the Renewable Fuel Standard, as described in Table 1. 
Figure 5: Ethanol Producer Price and Cost Structure

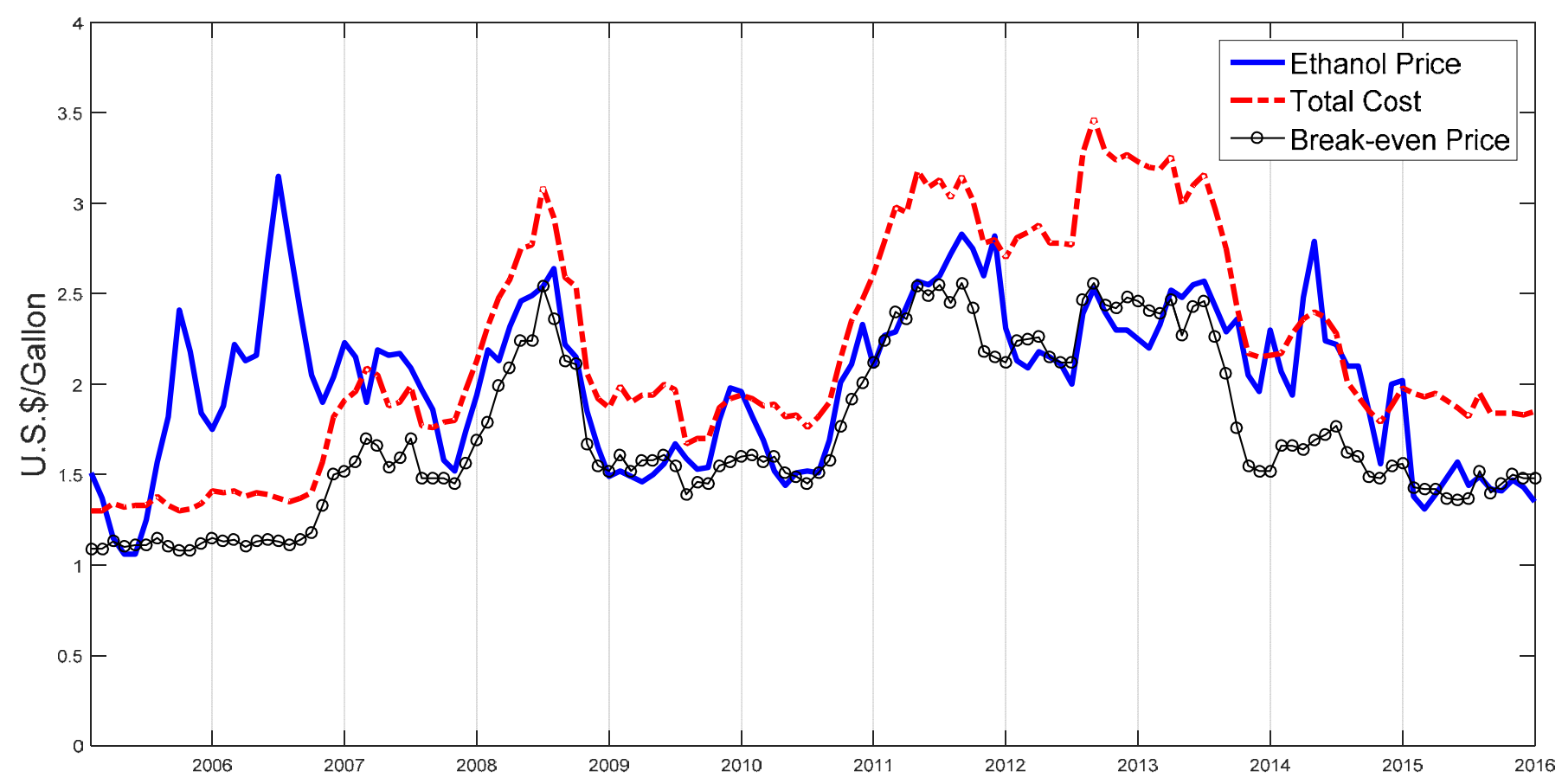

Source: Hofstrand (2016). The breakeven price is the total cost minus indirect subsidies to ethanol producers.

Figure 6: Spot Price of Unfinished Gasoline and Spot Price of Brent Crude Oil

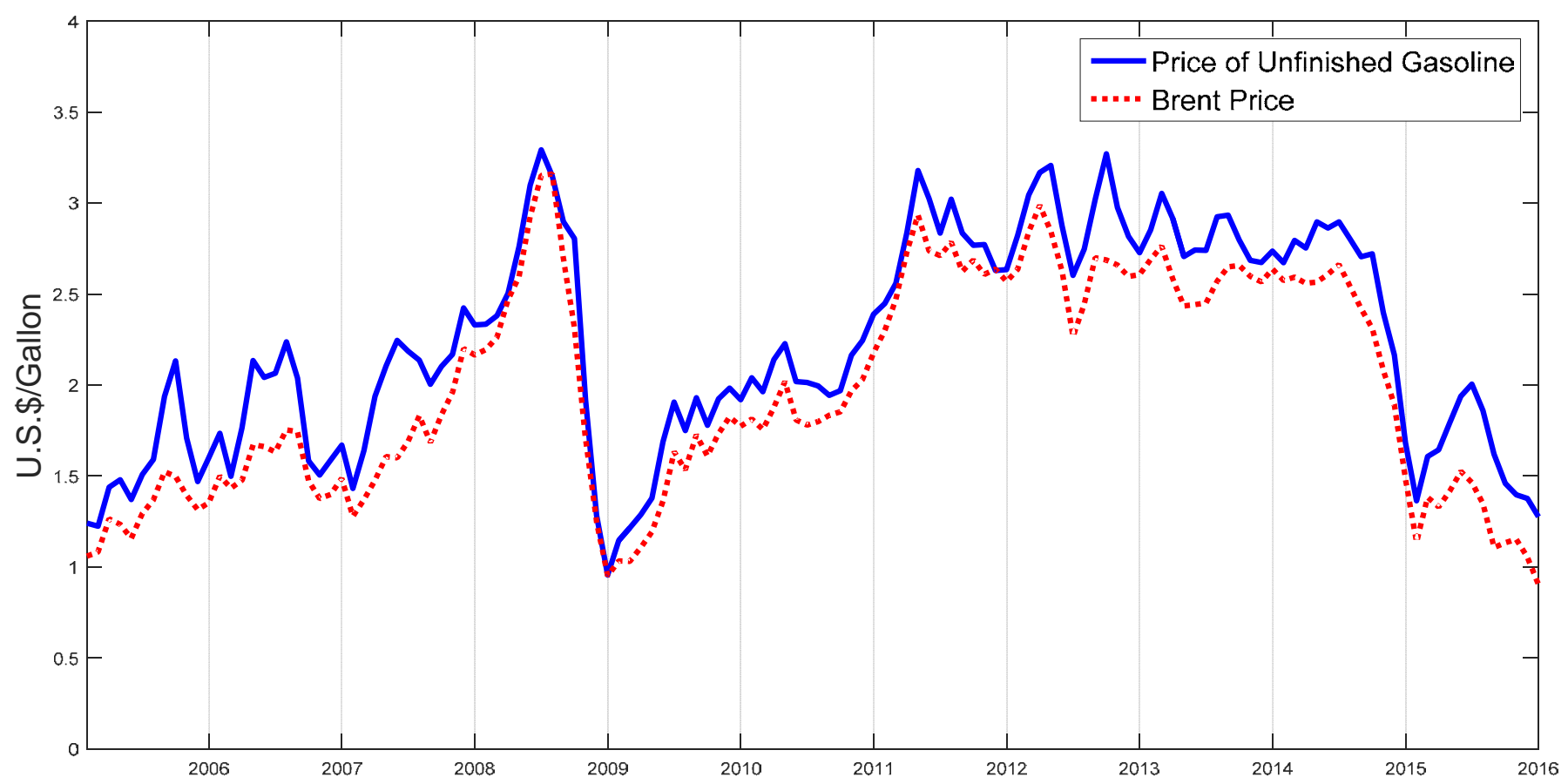

Source: EIA. 
Figure 7: Expectation of Ethanol Price and Counterfactual, 2005.1-2008.6
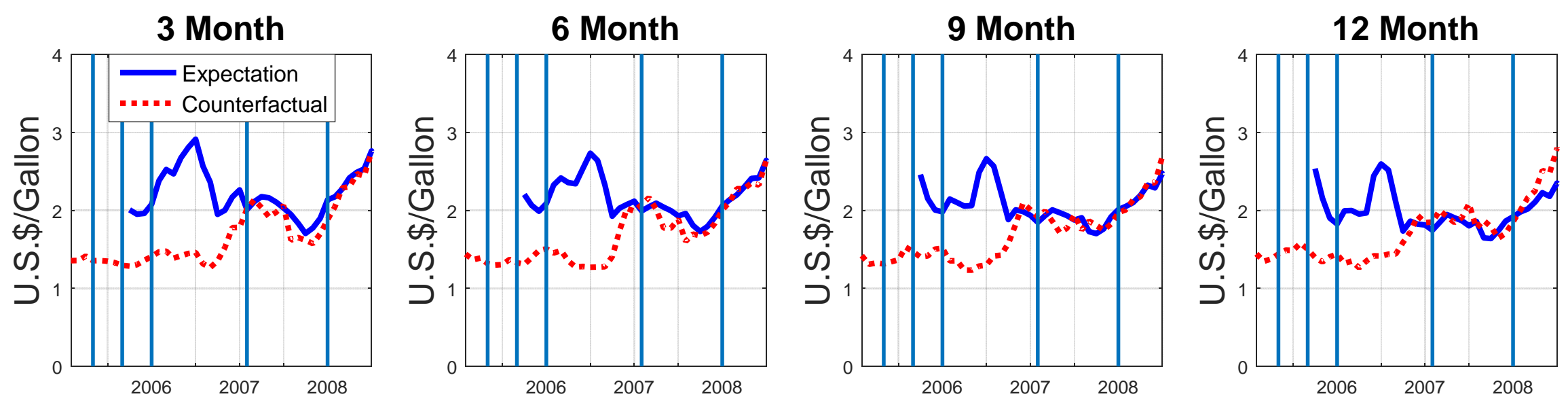

Source: Computations of the authors based on an adaptation of the term-structure model of Hamilton and Wu (2014). The vertical lines indicate proposed and actual changes to the RFS, as described in Table 1 . The horizontal line represents date $t$.

Figure 8: Ethanol Price Expectation - Counterfactual, 2005.1-2008.6
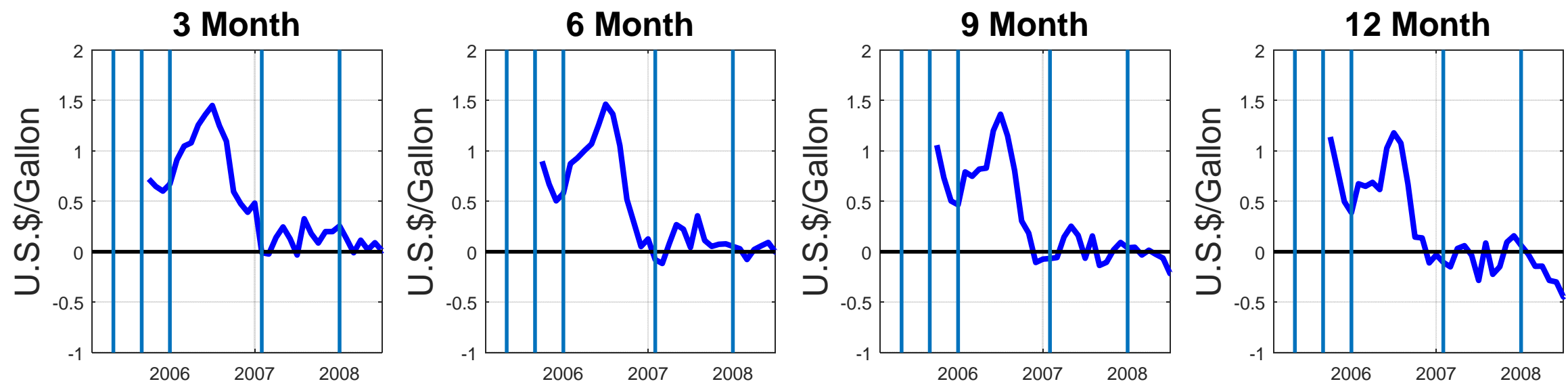

Source: See Figure 7. 
Figure 9: Long-Run versus Short-Run Ethanol Price Expectations
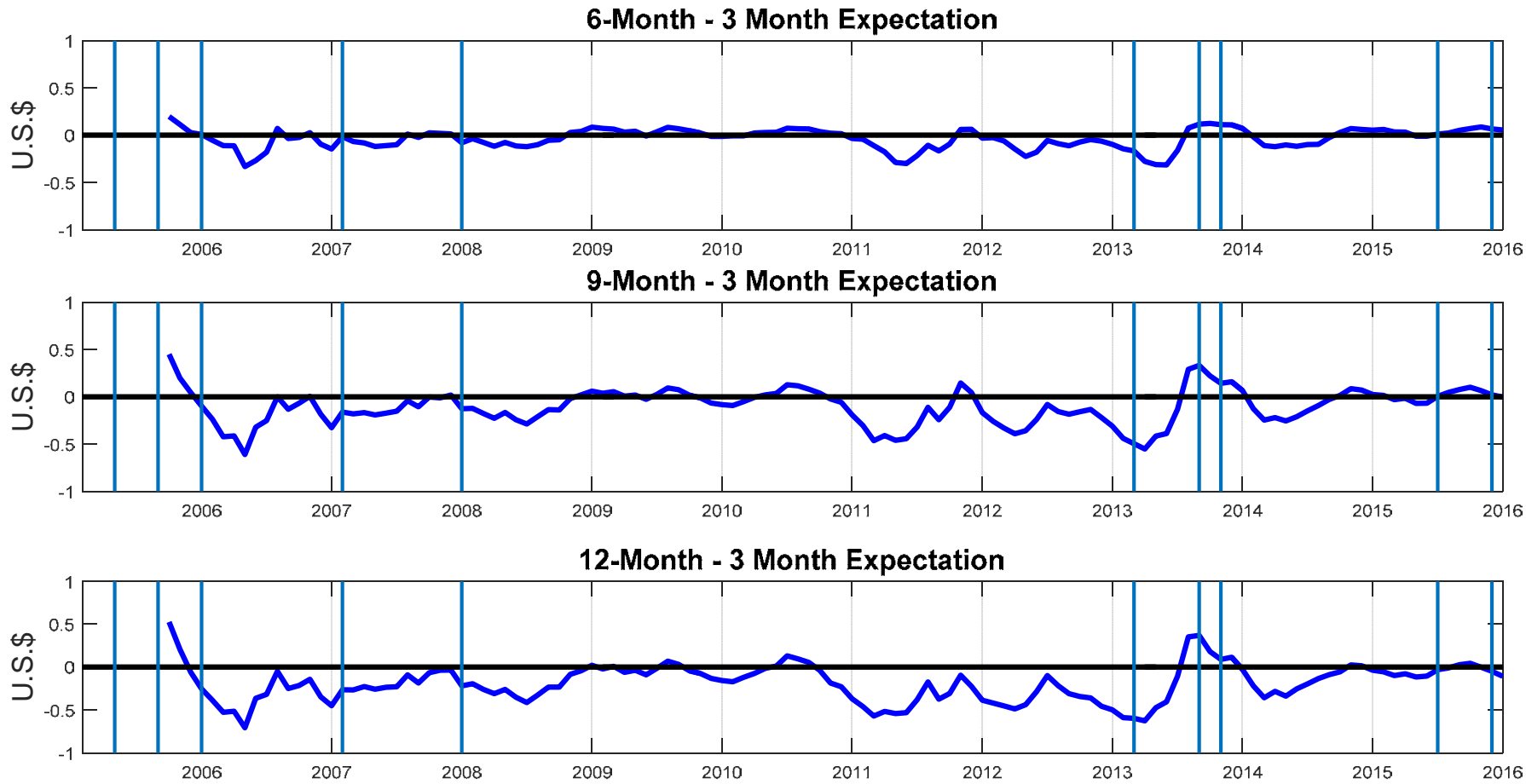

Source: See Figure 7.

Figure 10: The Relationship of the Market Prices of Ethanol and Corn
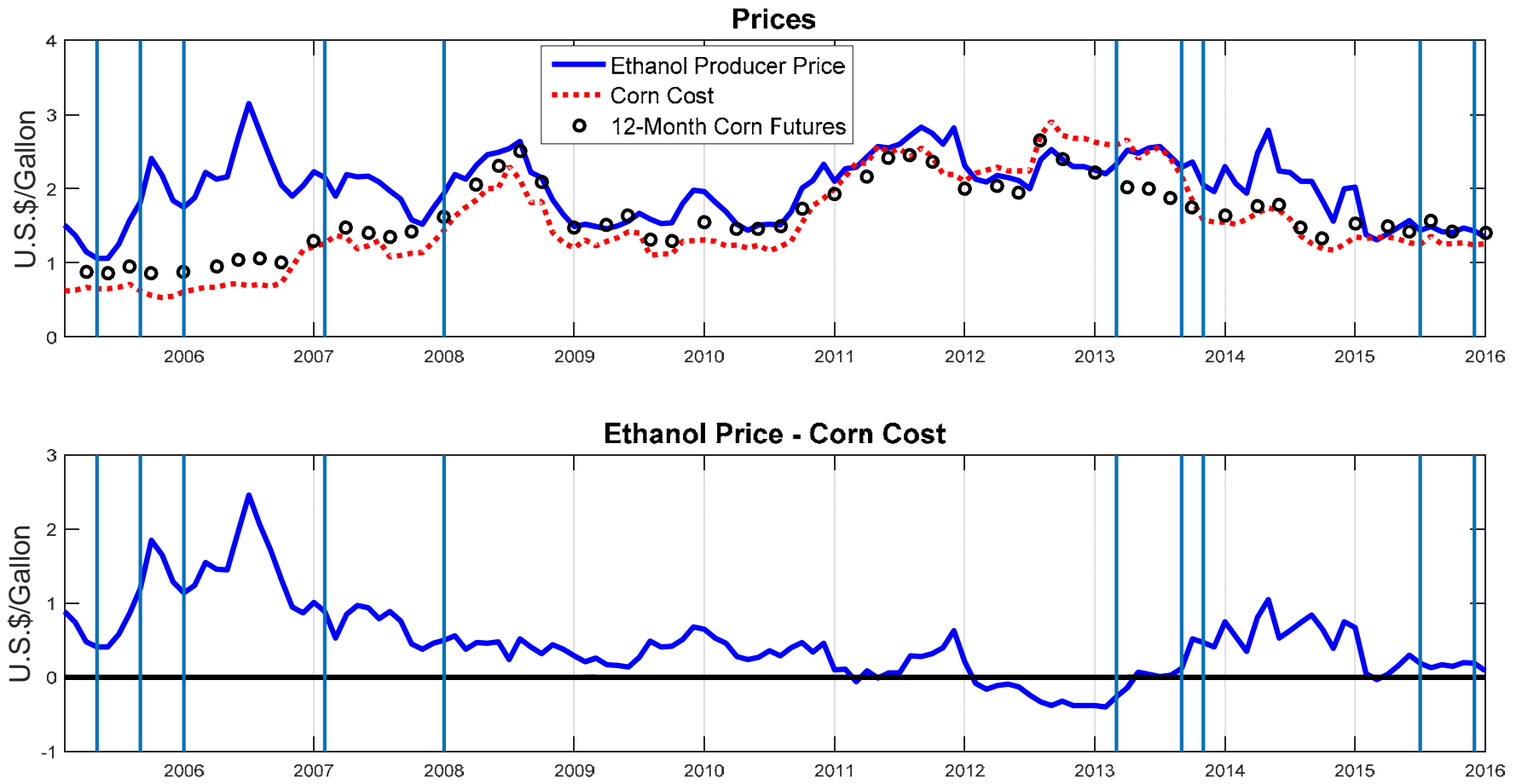

Source: Computations of the authors based on data from Hofstrand (2016) and Bloomberg. The corn futures prices are only available for selected months. 
Figure 11: Year-on-Year Percentage Change in U.S. Corn Stocks

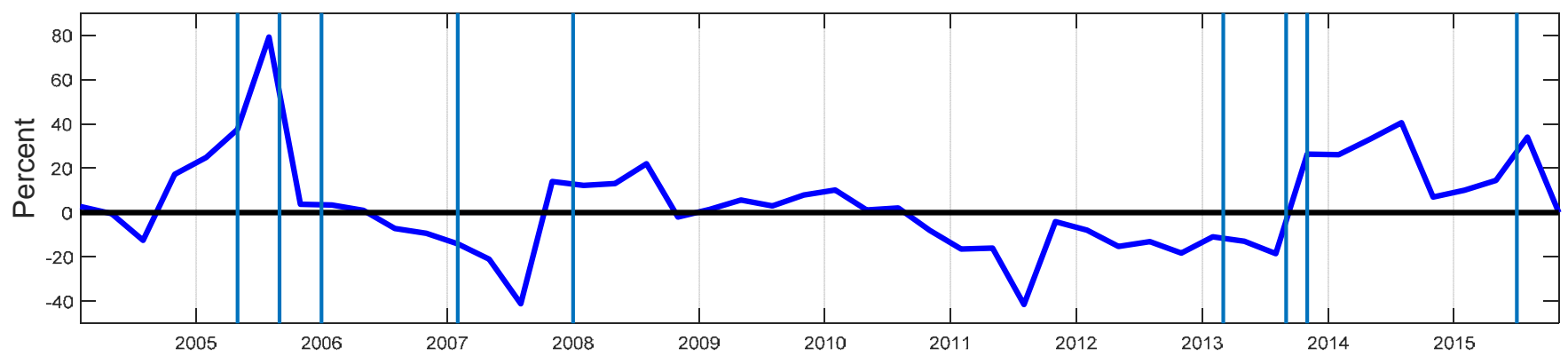

Source: Computed based on quarterly U.S. corn stocks reported by the U.S. Department of Agriculture.

Figure 12: Expected Breakeven Price Based on 12-Month Corn Futures Price

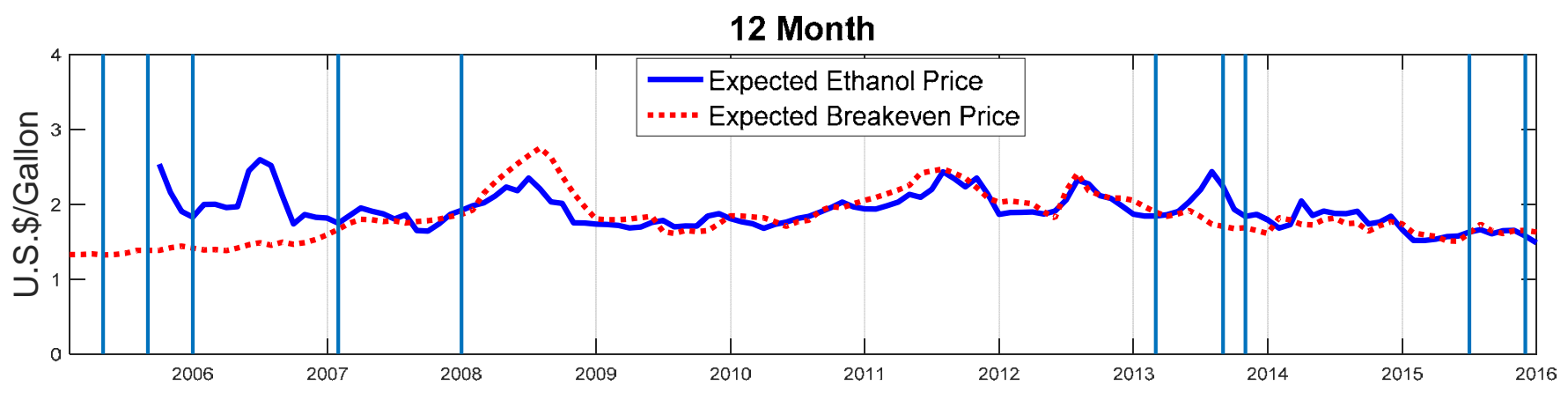

12 Month

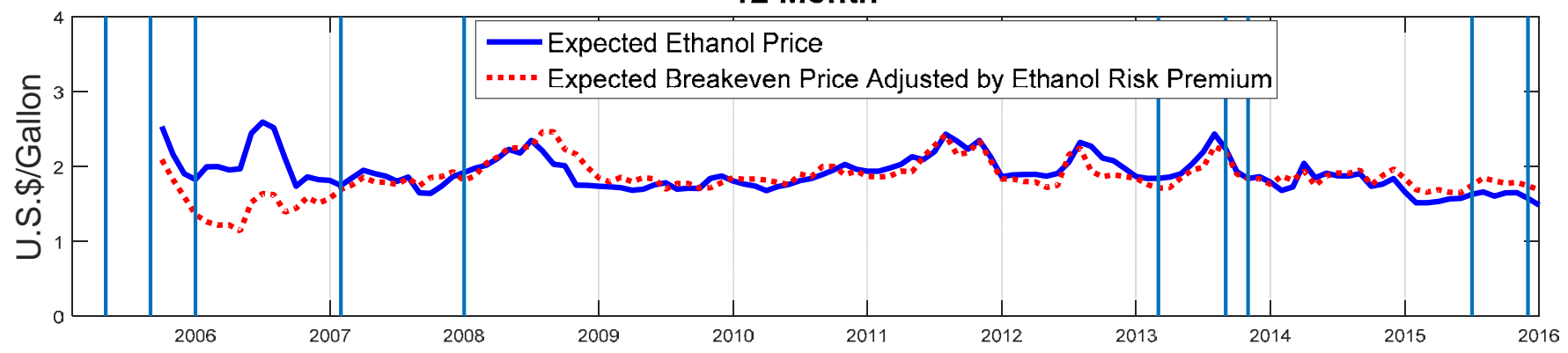

Source: The expected breakeven price in the upper panel is constructed by extrapolating the total corn cost component of the total cost of producing ethanol based on the expected percentage change in corn prices and subtracting the indirect subsidies. The expected change in corn prices is computed based on the linearly interpolated corn futures price, ignoring the risk premium. The lower panel shows the same expected breakeven price with the ethanol risk premium added to the futures price under the assumption that the 12-month corn and ethanol risk premia are identical. The horizontal line represents date on which the expectation is formed. The vertical lines indicate dates of proposed and actual changes to the Renewable Fuel Standard, as described in Table 1. 